\title{
In vivo experience with natural scaffolds for myocardial infarction: the times they are a-changin'
}

\author{
$\mid$ saac Perea-Gil ${ }^{1}$, Cristina Prat-Vidal ${ }^{*}$ and Antoni Bayes-Genis ${ }^{1,2}$
}

\begin{abstract}
Treating a myocardial infarction (MI), the most frequent cause of death worldwide, remains one of the most exciting medical challenges in the 21st century. Cardiac tissue engineering, a novel emerging treatment, involves the use of therapeutic cells supported by a scaffold for regenerating the infarcted area. It is essential to select the appropriate scaffold material; the ideal one should provide a suitable cellular microenvironment, mimic the native myocardium, and allow mechanical and electrical coupling with host tissues. Among available scaffold materials, natural scaffolds are preferable for achieving these purposes because they possess myocardial extracellular matrix properties and structures. Here, we review several natural scaffolds for applications in Ml management, with a focus on pre-clinical studies and clinical trials performed to date. We also evaluate scaffolds combined with different cell types and proteins for their ability to promote improved heart function, contractility and neovascularization, and attenuate adverse ventricular remodeling. Although further refinement is necessary in the coming years, promising results indicate that natural scaffolds may be a valuable translational therapeutic option with clinical impact in Ml repair.
\end{abstract}

\section{Introduction}

Myocardial infarction (MI) occurs when coronary artery blood flow is blocked. Currently, MI remains the most frequent cause of death worldwide [1]. In the United States alone, approximately 8 million people per year have a MI episode [2]. For effective MI treatment, it is necessary to limit adverse ventricular remodeling,

\footnotetext{
* Correspondence: cprat@igtp.cat

'ICREC (Heart Failure and Cardiac Regeneration) Research Lab, Health Sciences Research Institute Germans Trias i Pujol (IGTP). Cardiology Service, Hospital Universitari Germans Trias i Pujol, 08916 Badalona, Barcelona, Spain Full list of author information is available at the end of the article
}

attenuate myocardial scar expansion, enhance cardiac function and regeneration, and preserve synchronous contractility. Among the current therapies, only heart transplantation can fully achieve all these outcomes. Nonetheless, transplantation is highly limited by heart donor availability and host immunological response against the donated organ [3].

An alternative, novel therapeutic option is to deliver cells into the injured myocardium; this approach was demonstrated to be safe and feasible $[4,5]$. To date, several cell types have been used for cardiac regeneration, including embryonic stem cells (ESCs) [6], cardiomyocytes (CMs) derived from induced pluripotent stem cells (iPSCs) [7], mesenchymal stem cells (MSCs) [8], bone marrow MSCs [9], cardiac stem cells [10], cardiac progenitor cells [11], skeletal myoblasts [12], endothelial cells (ECs) [13], adipose tissue-derived stem cells (ATDSCs) [14], and CMs [15]. However, modest results have been obtained due to massive cell loss after administration, low cellular survival or lack of cellular effect triggered by hypoxic conditions in the host tissue, failure to establish electrical or mechanical heart coupling, which results in arrhythmias, and low rates of cell differentiation into a cardiac lineage [3]. To overcome these limitations, new methods for enhancing the final outcome have been proposed.

Cardiac tissue engineering offers a plausible solution to the drawbacks encountered previously. This alternative consists of seeding cells onto a structural, supportive platform, known as a scaffold, and may also be supplemented with cytokines, growth factors, or peptides. The scaffold provides a biomimetic environment which resembles the physiological cardiac environment; thus, it favors cell attachment and differentiation, and it avoids direct administration of cells into an adverse environmental niche (that is, infarcted myocardium) [16, 17]. Therefore, an optimal scaffold for cardiac repair should recreate the myocardial microenvironment, structure, 
and three-dimensional organization, permit vascularization to ensure oxygen and nutrient flow to the cells, match electrical and mechanical requirements for proper host tissue coupling, be easily replaceable, and enhance cell survival and engraftment $[3,16,17]$.

Depending on the origin of scaffold material, scaffolds are divided into two groups: natural and synthetic. Although synthetic materials offer the ability to directly control and adjust scaffold properties, natural materials appear to be more biodegradable and biocompatible. In addition, natural materials can better recreate the native myocardial microenvironment [18], which is necessary for generating the optimal, most suitable scaffold.

Here, we review natural scaffolds and hydrogel applications developed to repair injured myocardium after a MI. We describe constructs of natural materials combined with different cell types and other elements, and we analyze the main outcomes of heart function recovery in pre-clinical MI models and in clinical trials currently available (Tables 1, 2, 3, 4, 5 and 6). This summary provides an in-depth view of the current state of natural scaffold use in cardiac tissue engineering. Finally, we discuss the positive and negative aspects of the latest investigations in the field of myocardial regeneration.

\section{Natural scaffold materials for myocardial regeneration}

In recent years, in vitro studies have consolidated our understanding of natural scaffold generation and their application in cardiac tissue engineering. This progress has enabled further investigation and improvements in this field, leading ultimately to in vivo progressive implantation of the developed scaffolds, supported by the positive results obtained in vitro (Fig. 1). In the following sections we review the most notable and latest improvements for in vivo MI treatment using different natural scaffold implantation methods (Fig. 2).

\section{Collagen}

Collagen, the predominant protein in mammalian extracellular matrix (ECM), provides structural support for maintaining tissue integrity and contributes to the specificity of ECM microenvironments [19]. Several optimal properties, such as being biocompatible, adhesive, suturable, porous and readily combined with other materials, have made collagen appropriate for use as a natural scaffold in tissue engineering applications [20-25].

In cardiac tissue engineering, collagen scaffolds promote cardiac commitment, vascularization, and electrical coupling, thus representing a good candidate platform for MI repair. Collagen scaffold-associated benefits have been observed in different MI models (Table 1). Specifically, collagen type I delivery 3 hours after induction of a MI, without cells or added growth factors, can prevent adverse ventricular remodeling and long-term deterioration of heart function [26]. Furthermore, collagen can increase angiogenesis, reduce cell death, and limit the area of fibrosis, although these therapeutic effects were lost when the collagen scaffold was administered 1 or 2 weeks post-MI [26]. Another study revealed similar results when they inserted a collagen type I patch into rats subjected to MI [27]. After 4 weeks, compared with infarcted rats without the collagen patch, those with the patch had reduced adverse ventricular remodeling, limited fibrosis propagation, and significantly greater blood vessel formation. Remarkably, cardiac function was significantly increased, with an improvement of approximately $25 \%$ in ejection fraction (EF) compared with non-treated infarcted animals [27]. These results were also confirmed in a rat MI model where the collagen type I-treated group showed attenuated left ventricular (LV) remodeling and increased angiogenesis, which promoted the formation of new connective vasculature between the scaffold and the host myocardium, pointing out the importance of the collagen scaffold itself [28].

In addition, constructs combining different growth factors, proteins, cells or other natural or biological materials onto collagen scaffolds have been placed over infarcted myocardium (Table 1). One study in rats delivered a collagen type I scaffold combined with MSCs and interleukin-10 to the infarcted area of the heart [29]. When analyzed 28 days after treatment, the group that received the scaffold combination exhibited higher EF (mean recovery of $7 \%$ ), a $40 \%$ increase in infarcted wall thickness, a higher collagen III/I ratio, and less apoptosis inside the implant compared with the group that received the scaffold alone. Of interest, lower CD80+ macrophage and higher regulatory $\mathrm{CD} 163+$ macrophage infiltration was detected in the ischemic zone when the scaffold was applied, suggesting less associated inflammatory response. Nonetheless, these parameters were not significantly different when rats were treated with MSCs combined with the collagen scaffold but without interleukin-10, lacking the expected combinatory positive effect of cells plus interleukin-10 [29]. Another study compared a noncrosslinked collagen scaffold and crosslinked collagen scaffolds (both collagen type I) with variable degrees of crosslinking to modulate the material stiffness [30]. All were seeded with ATDSCs and sutured into rats with cardiac infarction. Only the non-crosslinked scaffold presented high biocompatibility and complete adhesion to the heart; a mild inflammatory reaction was observed 7 and 30 days after implantation. Moreover, this scaffold retained approximately $25 \%$ of the seeded cells. However, heart contractility, cardiac function, and cell growth and survival were not assessed for all the scaffolds [30]. These gaps in assessment were partially covered in a later study which showed that, at 1 week and 1 month after 
Table 1 The principal in vivo studies using a collagen-based scaffold and the outcomes obtained

\begin{tabular}{|c|c|c|c|c|}
\hline Scaffold material & $\begin{array}{l}\text { Cell lines and/or other } \\
\text { components }\end{array}$ & $\begin{array}{l}\text { Ml } \\
\text { model }\end{array}$ & Main results & References \\
\hline \multirow[t]{12}{*}{ Collagen } & - & Mouse & $\begin{array}{l}\text { Negative ventricular remodeling prevented, deterioration } \\
\text { of heart function prevented, lack of inflammatory } \\
\text { response, angiogenesis } \uparrow \text {, fibrosis } \downarrow \text {, cell death } \downarrow\end{array}$ & {$[26]$} \\
\hline & - & Mouse & 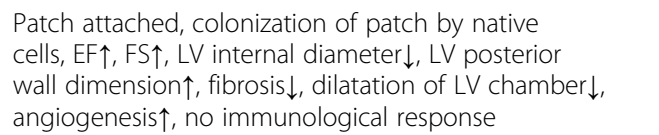 & [27] \\
\hline & - & Rat & $\begin{array}{l}\text { LV dilatation } \downarrow \text {, LV inner and outer diameters } \downarrow, \text { LV } \\
\text { pressure-volume curve shift (to the left towards } \\
\text { control), angiogenesis } \uparrow\end{array}$ & [28] \\
\hline & Rat MSCs+interleukin-10 & Rat & $\begin{array}{l}\mathrm{LV} E F \uparrow \text {, apoptosis } \downarrow \text {, infarcted wall average thickness } \uparrow, \\
\text { ratio collagen } I I / 1 \uparrow \text {, regulatory macrophage markers } \uparrow\end{array}$ & [29] \\
\hline & Rat ATDSCs & Rat & $\begin{array}{l}\text { Evaluation of inflammatory response to diverse } \\
\text { collagen scaffolds (non-crosslinked or crosslinked), } \\
\text { presence of cells in the non-crosslinked scaffold }\end{array}$ & {$[30]$} \\
\hline & Rat ATDSCs & $\begin{array}{l}\text { Rat and } \\
\text { pig }\end{array}$ & $\begin{array}{l}\text { Rat: cell engraftment } \uparrow, L V E F \uparrow \text {, stiffer mechanical } \\
\text { behavior, fibrosis } \downarrow \text {, revascularization } \uparrow \text {. Pig: LV EF } \uparrow \text {, } \\
\text { fibrosis } \downarrow \text {, vascularization } \uparrow\end{array}$ & [31] \\
\hline & Sheep adipose tissue MSCs & Sheep & $\begin{array}{l}\text { LV end-diastolic dimension improvement, diastolic } \\
\text { function } \uparrow \text {, angiogenesis } \uparrow \text {, fibrosis extension } \downarrow\end{array}$ & [32] \\
\hline & Rat bone marrow MSCs & Rat & $\begin{array}{l}\text { LV wall thickness } \uparrow, E F \text { preservation, FS } \uparrow \text {, fractional } \\
\text { area change } \uparrow\end{array}$ & [33] \\
\hline & Rat bone marrow MSCs & Rat & $\begin{array}{l}\text { Infarcted segment perfusion } \uparrow \text {, infarct area } \downarrow \text {, } \\
\text { contractility } \uparrow \text {, low inflammation, angiogenesis } \uparrow, \\
\text { ventricular wall thickness } \uparrow, \text { LV dilatation } \downarrow\end{array}$ & [34] \\
\hline & $\begin{array}{l}\text { Rat bone marrow MSCs } \\
\text { +glycosaminoglycans }\end{array}$ & Rat & No inflammation, neovascularization $\uparrow$, presence of cells & [35] \\
\hline & $\begin{array}{l}\text { Mouse Sca- } 1^{+} \text {cells (collagen } \\
\text { conjugated with anti-Sca-1 } \\
\text { antibody) }\end{array}$ & Mouse & $\begin{array}{l}\text { Number of infiltrated cells } \uparrow \text {, capillary density } \uparrow \text {, cell } \\
\text { density } \uparrow, \text { myocardium regeneration } \uparrow\end{array}$ & {$[36]$} \\
\hline & $\begin{array}{l}\text { Human mononuclear } \\
\text { bone marrow stem cells }\end{array}$ & Human & $\begin{array}{l}\text { No mortality or related adverse effects, New York Heart } \\
\text { Association functional class } \uparrow, \text { LV end-diastolic volume } \downarrow \text {, } \\
\text { LV filling deceleration time improvement, scar area } \\
\text { thickness } \uparrow, E F \uparrow\end{array}$ & {$[37,38]$} \\
\hline \multirow[t]{2}{*}{ Collagen+chitosan } & Encapsulated thymosin $\beta 4$ & Rat & Cardiac tissue loss $\downarrow$, vascularization $\uparrow$ & [25] \\
\hline & $\begin{array}{l}\text { Integrin-binding, angiopoietin- } \\
\text { 1-derived peptide QHREDGS }\end{array}$ & Rat & $\begin{array}{l}\text { Cardiac function } \uparrow, \text { scar thickness and scar area fraction } \\
\text { improved, presence of CMs } \uparrow \text {, no inflammation }\end{array}$ & [39] \\
\hline $\begin{array}{l}\text { Collagen+oligo (acryloyl carbonate)- } \\
\text { poly(ethylene glycol)-oligo(acryloyl } \\
\text { carbonate) }\end{array}$ & Rat bone marrow MSCs & Rat & $\begin{array}{l}\text { Preserved EF, infarct size } \downarrow \text {, LV wall thickness } \uparrow \text {, vessel } \\
\text { density } \uparrow\end{array}$ & [41] \\
\hline
\end{tabular}

ATDSC adipose tissue-derived stem cell, $C M$ cardiomyocyte, EF ejection fraction, $F S$ fractional shortening, $L V$ left ventricle/left ventricular, $M I$ myocardial infarction, MSC mesenchymal stem cell, Sca stem cell antigen

implantation, the non-crosslinked collagen scaffold seeded with ATDSCs displayed more cell engraftment than ATDSC administration alone [31]. In addition, in both rat and pig chronic MI models, the groups that received both collagen and cells had significant increases in heart function (approximately $16 \%$ ) and revascularization, and a significant decrease in fibrotic area 4 months post-treatment compared with untreated animals and animals treated with either scaffold alone or cells alone. The reduction in collagen content of treated animals could be explained by the lower detected levels of procollagen C-proteinase and lysyl oxidase, reducing collagen crosslinking [31]. Similar results were obtained in a sheep MI model, in terms of cardiac function recovery and revascularization [32], thus indicating the suitability and promise of combined administration of collagen scaffold and ATDSCs. In addition, bone marrow MSCs combined with a collagen type I platform also preserved heart function after up to 6 weeks of treatment, in contrast to infarcted groups that were not treated or treated with cells only [33]. Further experiments demonstrated that bone marrow MSCs in a collagen type I scaffold had beneficial effects on contractility, wall thickness, angiogenesis, and infarcted area perfusion, and curbed ventricular dilatation and infarct zone expansion [34]. 
Table 2 Main achievements in myocardial infarction recovery after the administration of a fibrin scaffold

\begin{tabular}{|c|c|c|c|c|}
\hline Scaffold material & Cell lines and/or other components & Ml model & Main results & References \\
\hline \multirow[t]{13}{*}{ Fibrin } & Rat skeletal myoblasts & Rat & FS and infarct wall thickness preservation & {$[52]$} \\
\hline & Rat skeletal myoblasts & Rat & Infarct scar size $\downarrow$, arteriole density $\uparrow$ & [53] \\
\hline & $\begin{array}{l}\text { Human cardiac and subcutaneous } \\
\text { ATDPCs }\end{array}$ & Mouse & $\begin{array}{l}\text { CM and EC differentiation, vessel density } \uparrow, \mathrm{LV} E F \uparrow \text {, infarct } \\
\text { size } \downarrow\end{array}$ & [55] \\
\hline & Rat bone marrow cells & Rat & $\begin{array}{l}\text { Cell retention } \uparrow, \text { LV perimeter } \downarrow \text {, stroke volume and } \\
\text { contractility preservation, cardiac function } \uparrow\end{array}$ & {$[56]$} \\
\hline & hESCs & $\begin{array}{l}\text { Mouse } \\
\text { and pig }\end{array}$ & $\begin{array}{l}\text { Cardiac function } \uparrow \text {, cell engraftment } \uparrow \text {, angiogenesis } \uparrow, E F \uparrow, \\
\text { infarct size } \downarrow \text {, LV hypertrophy } \downarrow \text {, systolic LV wall stress } \downarrow \text {, LV } \\
\text { systolic thickening fraction } \downarrow\end{array}$ & {$[57]$} \\
\hline & Rat adipose-derived MSCs & Rat & $\begin{array}{l}\text { Preserved wall thickness, LV end-diastolic and systolic } \\
\text { dimensions } \downarrow \text {, LV end-diastolic volume } \downarrow \text {, LV end-systolic } \\
\text { volume } \downarrow, \text { LV remodeling suppressed }\end{array}$ & [58] \\
\hline & hESC-derived cardiac progenitors & Rat & $\begin{array}{l}\text { LV end-systolic volume } \downarrow \text {, EF } \uparrow \text {, angiogenesis } \uparrow \text {, absence of } \\
\text { teratomas }\end{array}$ & [59] \\
\hline & $\begin{array}{l}\text { Human iPSC-derived CMs, ECs, and } \\
\text { smooth muscle cells }\end{array}$ & Pig & $\begin{array}{l}\text { Cell survival } \uparrow, \text { LV EF } \uparrow \text {, contractility } \uparrow \text {, infarct size } \downarrow \text {, regional wall } \\
\text { stress } \downarrow \text {, energetic efficiency } \uparrow \text {, lack of arrhythmias, apoptosis } \downarrow \text {, } \\
\text { cellular expression of Nkx } 2.5 \uparrow \text {, angiogenesis } \uparrow \text {, immune } \\
\text { response delayed, protective paracrine effects }\end{array}$ & {$[54]$} \\
\hline & $\begin{array}{l}\text { Rat heart cells; native population or } \\
\text { CM-depleted population }\end{array}$ & Rat & $\begin{array}{l}\text { EF and FS } \uparrow \text { (only for patch with native cell population), } \\
\text { wall thickness } \uparrow \text {, infarct size } \downarrow \text {, cell migration, } \\
\text { vascularization } \uparrow \text {, electrical coupling and alignment not } \\
\text { achieved }\end{array}$ & {$[60]$} \\
\hline & Human umbilical cord blood MSCs & Mouse & Infarct size $\downarrow$, vessel density $\uparrow$ & [61] \\
\hline & Human umbilical cord blood MSCs & Mouse & Microvasculature formation $\uparrow, \mathrm{FS} \uparrow, \mathrm{EF} \uparrow$ & [62] \\
\hline & Swine MSCs & Pig & $\begin{array}{l}\text { LV thickness fraction } \uparrow \text {, neovascularization } \uparrow \text {, differentiation } \\
\text { into myocyte-like cell lineage }\end{array}$ & [63] \\
\hline & Swine MSCs+thymosin $\beta 4$ & Rat & 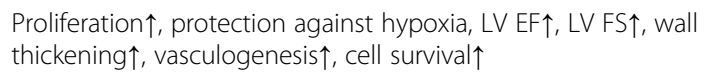 & [64] \\
\hline Fibrin+PEG & SDF-1a & Mouse & 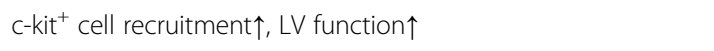 & [68] \\
\hline $\begin{array}{l}\text { Fibrin+decellularized } \\
\text { myocardial ECM }\end{array}$ & $\begin{array}{l}\text { Human mesenchymal progenitor } \\
\text { cells (TGF- } \beta \text {-conditioned or not) }\end{array}$ & Rat & $\begin{array}{l}\text { Angiogenesis } \uparrow \text {, cell migration } \uparrow, \text { LV diameter and area } \\
\text { preservation, contractility } \uparrow\end{array}$ & {$[70]$} \\
\hline
\end{tabular}

ATDPC adipose tissue-derived progenitor cell, $C M$ cardiomyocyte, $E C$ endothelial cell, ECM extracellular matrix, EF ejection fraction, $F S$ fractional shortening, hESC human embryonic stem cell, iPSC induced pluripotent stem cell, $L V$ left ventricle/left ventricular, MI myocardial infarction, MSC mesenchymal stem cell, PEG polyethylene glycol, SDF stromal cell-derived factor, TGF transforming growth factor

Moreover, when the collagen type I and bone marrow MSC combination was supplemented with glycosaminoglycans, the results demonstrated reduced inflammation, increased neovascularization, and improved retention of cells, but no LV function parameters were evaluated [35]. In another study, collagen type I was conjugated with antibodies that specifically recognized stem cell antigen-1 (Sca-1), a surface marker for hematopoietic, cardiac, and muscle stem cells. These antibodies enriched the scaffold by capturing Sca- $1^{+}$cells. When this scaffold combination was applied to the infarcted myocardium, it retained a high number of cells, increased cardiac tissue regeneration, and expanded capillary density compared with infarcted hearts that did not receive the enriched scaffold. It is important to emphasize that scaffolds with Sca-1 showed faster degradation of the collagen scaffold, and fiber arrangement was better organized [36].

In the Myocardial Assistance by Grafting a New bioartificial Upgraded Myocardium (MAGNUM) clinical trial, the delivery, safety, and effectiveness of a collagen type I scaffold loaded with autologous bone marrow MSCs was tested in humans (Tables 1 and 6) [37]. In this study, a total of 20 patients with myocardial ischemia that displayed indications for bypass surgery were included and divided into two treatment groups: one group $(n=10)$ was treated with cells only, and the other group $(n=10)$ received the collagen scaffold with cells. After completing a 10-month follow-up, no adverse events or death occurred. With both treatments, patients experienced improvements in EF and the New York Heart Association functional class. Compared with the group treated with cells alone, the scaffold-plus-cells treatment group showed enhanced LV end-diastolic volume, LV filling deceleration time, and scar area thickness, which indicated LV function improvement and limited adverse remodeling. Therefore, the collagen scaffold with cells was demonstrated to be both safe and effective for treating ischemia in humans compared with administration of cells alone [38]. These 
Table 3 In vivo improvements achieved with scaffolds composed of the polysaccharides chitosan, alginate or hyaluronic acid

\begin{tabular}{|c|c|c|c|c|}
\hline Scaffold material & $\begin{array}{l}\text { Cell lines and/or other } \\
\text { components }\end{array}$ & Ml model & Main results & References \\
\hline \multirow[t]{5}{*}{ Chitosan } & Rat brown ATDSCs & Rat & $\begin{array}{l}\text { Cell survival and retention } \uparrow, E F \uparrow, F S \uparrow, \text { LV end-diastolic } \\
\text { pressure } \downarrow \text {, LV pressure change } \uparrow \text {, infarct size } \downarrow \text {, fibrosis } \downarrow \text {, } \\
\text { ATDSC to cardiac lineage differentiation } \uparrow \text {, vessel density } \uparrow \text {, } \\
\text { endothelial and smooth muscle cell differentiation }\end{array}$ & [81] \\
\hline & Mouse ESCs & Rat & 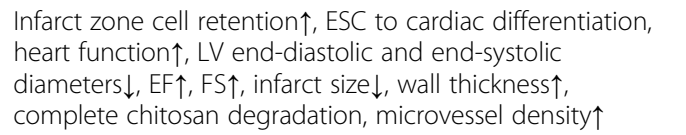 & {$[82]$} \\
\hline & $\begin{array}{l}\text { Mouse nuclear-transferred ESCs or } \\
\text { fertilization-derived mouse ESC }\end{array}$ & Rat & $\begin{array}{l}\text { For both cell types: infarcted area covered } \uparrow \text {, possible } \\
\text { differentiation into CMs, smooth muscle cells and ECs, } \\
\text { heart function } \uparrow, \mathrm{LV} \text { end-diastolic and end-systolic } \\
\text { diameters } \downarrow \text {, EF } \uparrow, \mathrm{FS} \uparrow \text {, infarct size } \downarrow \text {, wall thickness } \uparrow \\
\text { complete chitosan degradation, neovascularization } \uparrow\end{array}$ & {$[83]$} \\
\hline & bFGF & Rat & $\begin{array}{l}\mathrm{LV} E F \uparrow, \mathrm{LV} F S \uparrow \text {, arteriole density } \uparrow \text {, infarct size } \downarrow \text {, fibrosis } \\
\text { area } \downarrow\end{array}$ & [84] \\
\hline & RoY peptide & Rat & $\begin{array}{l}\text { Angiogenesis } \uparrow \text {, ventricular wall thickness } \uparrow \text {, fibrosis } \downarrow \text {, } \\
\text { infarct size } \downarrow \text {, LV FS } \uparrow, L V E F \uparrow\end{array}$ & {$[85]$} \\
\hline \multirow[t]{2}{*}{ Chitosan+alginate } & Rat MSCs & Rat & $\mathrm{EF} \uparrow, \mathrm{LV}$ function $\uparrow$, angiogenesis $\uparrow$ & [77] \\
\hline & - & Rat & $\begin{array}{l}\text { Angiogenesis } \uparrow \text {, no inflammation exacerbation, apoptosis } \downarrow \text {, } \\
\text { presence of c-kit }{ }^{+} \text {cells } \uparrow \text {, proliferation } \uparrow \text {, wall thickness } \uparrow, \mathrm{LV} \\
\text { expansion } \downarrow \text {, LV EF } \uparrow\end{array}$ & [87] \\
\hline \multirow[t]{10}{*}{ Alginate } & - & Rat & $\begin{array}{l}\text { Absence of arrhythmias or thrombus formation, scaffold } \\
\text { degraded, scar thickness } \uparrow \text {, diastolic and systolic anterior } \\
\text { wall thicknesses } \uparrow, \text { LV end-diastolic and systolic } \\
\text { dimensions } \downarrow \text {, LV end-diastolic and systolic areas } \downarrow \text {, cardiac } \\
\text { dysfunction } \downarrow\end{array}$ & {$[98]$} \\
\hline & - & Dog & 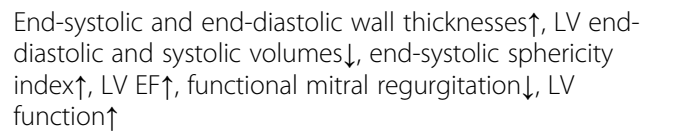 & [99] \\
\hline & - & Pig & $\begin{array}{l}\text { No arrhythmias or conduction blocks, no remote infarcts } \\
\text { in other organs, LV enlargement } \downarrow, L V \text { function } \uparrow \text {, coronary } \\
\text { blood flow not affected, scar thickness } \uparrow \text {, anterior wall } \\
\text { thickness } \uparrow\end{array}$ & [100] \\
\hline & Rat fetal cardiac cells & Rat & $\begin{array}{l}\text { Vascularization } \uparrow \text {, formation of myofibers and gap junctions, } \\
\text { preservation of LV dimensions and FS }\end{array}$ & [102] \\
\hline & $\begin{array}{l}\text { Human ESCs or human embryonic } \\
\text { bodies }\end{array}$ & Rat & 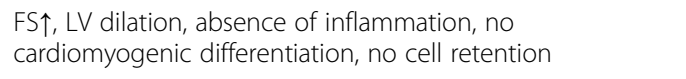 & [103] \\
\hline & RGD peptide & Rat & FS $\uparrow$, LV dimension $\downarrow$, LV wall thickness $\uparrow$, angiogenesis $\uparrow$ & [105] \\
\hline & $\begin{array}{l}\text { RGD peptide+encapsulated MSCs } \\
\text { (microbeads) }\end{array}$ & Rat & $\begin{array}{l}\text { LV function } \uparrow \text {, wall thickness preservation, LV internal } \\
\text { dimensions preserved, infarct size } \downarrow \text {, angiogenesis } \uparrow \text {, high } \\
\text { cell retention }\end{array}$ & {$[106]$} \\
\hline & $\begin{array}{l}\text { Unmodified alginate; RGD or YIGSR } \\
\text { peptide-modified alginate; or RGE } \\
\text { peptide-modified alginate }\end{array}$ & Rat & $\begin{array}{l}\text { Unmodified-alginate: scar thickness } \uparrow \text {, attenuated LV } \\
\text { systolic and diastolic dilatations, LV FS } \uparrow \text {, fractional area } \\
\text { change } \uparrow, \text { LV expansion index } \downarrow \text { (compared with all } \\
\text { peptide-modified alginates) }\end{array}$ & [107] \\
\hline & IGF/HGF (microbeads) & Rat & $\begin{array}{l}\text { Scar thickness preservation, infarct expansion index } \downarrow \text {, scar } \\
\text { collagen accumulation } \downarrow \text {, vascularization } \uparrow \text {, apoptosis } \downarrow\end{array}$ & [110] \\
\hline & - & Human & $\begin{array}{l}\text { New York Heart Association functional class } \uparrow, \text { Kansas City } \\
\text { Cardiomyopathy Questionnaire score } \uparrow\end{array}$ & [111] \\
\hline Alginate+fibrin & - & Pig & $\begin{array}{l}\text { LV posterior wall thickness } \uparrow \text {, infarct expansion } \downarrow \text {, } \\
\text { extractable collagen } \downarrow\end{array}$ & [115] \\
\hline $\begin{array}{l}\text { Alginate+Matrigel } \\
\text { +omentum }\end{array}$ & $\begin{array}{l}\text { Neonatal rat cardiac cells with } \\
\text { SDF-1, IGF-1 and VEGF }\end{array}$ & Rat & $\begin{array}{l}\text { Mechanical and electrical coupling, relative scar } \\
\text { thickness } \uparrow \text {, angiogenesis } \uparrow \text {, infarct expansion index } \downarrow \text {, FS } \\
\text { and fractional area change preserved, LV end-diastolic } \\
\text { and systolic dimensions } \downarrow\end{array}$ & [117] \\
\hline
\end{tabular}


Table 3 In vivo improvements achieved with scaffolds composed of the polysaccharides chitosan, alginate or hyaluronic acid (Continued)

\begin{tabular}{|c|c|c|c|c|}
\hline \multirow[t]{10}{*}{ Hyaluronic acid } & Alone or with VEGF & Rat & $\begin{array}{l}\text { Ventricle thickness } \uparrow \text {, infarct size } \downarrow \text {, apoptosis } \downarrow \text {, } \\
\text { vascularization } \uparrow \text {, heart function } \uparrow\end{array}$ & [121] \\
\hline & Rat BMMNCs & Rat & $\begin{array}{l}\text { Apoptosis } \downarrow \text {, inflammatory response } \downarrow \text {, EF } \uparrow \text {, ventricular } \\
\text { dilatation } \downarrow \text {, scar size } \downarrow \text {, collagen content } \downarrow \text {, angiogenesis } \uparrow \text {, } \\
\text { cell differentiation into ECs }\end{array}$ & [124] \\
\hline & Pig BMMNCs & Pig & $\begin{array}{l}\mathrm{LV} E F \uparrow \text {, interventricular septum thickness } \uparrow, \mathrm{LV} \text { end-diastolic } \\
\text { pressure and volume } \downarrow \text {, contractility } \uparrow \text {, scar size and length } \downarrow \text {, } \\
\text { fibrosis } \downarrow \text {, high cell retention, neovascularization } \uparrow\end{array}$ & [125] \\
\hline & $\begin{array}{l}\text { Rat bone marrow MSCs (esterified } \\
\text { hyaluronic acid) }\end{array}$ & Rat & Construct integration, vascularization $\uparrow$, fibrosis $\downarrow$ & [126] \\
\hline & $\begin{array}{l}\text { Pig bone marrow MSCs (esterified } \\
\text { hyaluronic acid) }\end{array}$ & Pig & Inflammation $\downarrow$, fibrosis $\downarrow$, degeneration of cardiac cells $\downarrow$ & [127] \\
\hline & $\begin{array}{l}\text { Hydroxyethyl methacrylate, } \\
\text { SDF-1a, mouse bone marrow cells }\end{array}$ & Mouse & Cell homing in the myocardium $\uparrow$ & [128] \\
\hline & rTIMP-3 & Pig & $\begin{array}{l}\text { LV end-diastolic dimension } \downarrow \text {, LV EF } \uparrow \text {, wall stress } \downarrow \text {, infarct } \\
\text { expansion } \downarrow \text {, wall thickness } \uparrow \text {, LV end-diastolic volume } \\
\text { preserved, myofibroblast number } \uparrow \text {, collagen content } \uparrow\end{array}$ & [130] \\
\hline & Gelin-S & Rat & 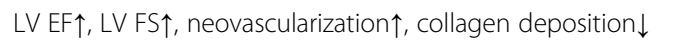 & [131] \\
\hline & Methacrylic anhydride & Sheep & $\begin{array}{l}\text { Regional wall thickness } \uparrow \text {, infarcted area } \downarrow \text { (only for highly } \\
\text { stiff scaffold) }\end{array}$ & [132] \\
\hline & $\begin{array}{l}\text { Methacrylic anhydride or/and } \\
\text { hydroxyethylmethacrylate }\end{array}$ & Sheep & $\begin{array}{l}\text { Wall thickness } \uparrow \text {, vascularization } \uparrow \text {, inflammation } \uparrow, \text { LV end- } \\
\text { systolic volume } \downarrow \text { (only for highly stiff, stable scaffold) }\end{array}$ & [133] \\
\hline Hyaluronic acid+gelatin & Human cardiosphere-derived cells & Mouse & $\begin{array}{l}\text { Cardiac function } \uparrow, \text { LV remodeling and abnormal heart } \\
\text { morphology } \downarrow \text {, viable tissue } \uparrow \text {, wall thickness } \uparrow \text {, cardiac and } \\
\text { endothelial cellular differentiation, cellular engraftment } \uparrow \text {, } \\
\text { neovascularization } \uparrow \text {, apoptosis } \downarrow\end{array}$ & [134] \\
\hline $\begin{array}{l}\text { Hyaluronic acid+silk } \\
\text { fibroin }\end{array}$ & Rat bone marrow MSCs & Rat & $\begin{array}{l}\text { LV inner diameter } \downarrow \text {, wall thickness } \uparrow, F S \uparrow \text {, inflammation } \downarrow \text {, } \\
\text { apoptosis } \downarrow \text {, vascularization } \uparrow \text {, a-MHC expression } \uparrow \text {, paracrine } \\
\text { factor secretion } \uparrow\end{array}$ & [135] \\
\hline $\begin{array}{l}\text { Hyaluronic acid+chitosan } \\
\text { +silk fibroin }\end{array}$ & - & Rat & $\begin{array}{l}\text { LV inner diameter } \downarrow \text {, wall thickness } \uparrow, \text { LV FS } \uparrow \text {, angiogenesis } \uparrow \text {, } \\
\text { paracrine factor expression } \uparrow\end{array}$ & [136] \\
\hline $\begin{array}{l}\text { Hyaluronic acid+butyric } \\
\text { and retinoic acids }\end{array}$ & Human placenta-derived MSCs & Pig & $\begin{array}{l}\text { Scar size } \downarrow \text {, infarct core zone } \downarrow \text {, angiogenesis } \uparrow \text {, fibrosis } \downarrow \text {, } \\
\text { end-systolic wall thickening and circumferential shortening } \uparrow \text {, } \\
\text { high homology with healthy myocardium }\end{array}$ & {$[137]$} \\
\hline
\end{tabular}

ATDSC adipose tissue-derived stem cell, $b F G F$ basic fibroblast growth factor, BMMNC bone marrow mononuclear cell, $C M$ cardiomyocyte, $E C$ endothelial cell, $E F$ ejection fraction, ESC embryonic stem cell, FS fractional shortening, HGF hepatocyte growth factor, IGF insulin growth factor, $L V$ left ventricle/left ventricular, MHC myosin heavy chain, MI myocardial infarction, MSC mesenchymal stem cell, rTIMP recombinant tissue inhibitor of matrix metalloproteinases, SDF stromal cellderived factor, VEGF vascular endothelial growth factor

positive results should encourage further investigation following administration of combined collagen scaffold and MSCs, recruiting more patients and extending the clinical trial follow-up.

With regard to combinations of natural or biological materials, a mixture of chitosan, collagen type I, and encapsulated thymosin $\beta 4$ was used to treat a rat MI model, with diverse results (Table 1). At 3 weeks after MI induction, treated rats showed reduced tissue loss (only $13 \%$ compared with $58 \%$ and $30 \%$ for non-treated and thymosin $\beta 4$-free hydrogel-treated animals, respectively) and enhanced vascularization compared with untreated animals or thymosin $\beta 4$-treated animals, but no functional benefits were achieved [25]. When the integrin-binding, angiopoietin-1derived peptide QHREDGS was attached to the same collagen and chitosan scaffold, infarcted animals displayed abundant CMs, no inflammatory response, and, more importantly, improved cardiac function [39].

Finally, collagen combined with synthetic materials would retain the properties of collagen (that is, degradability and compatibility) and could provide a means to recreate a natural, appropriate microenvironment, which could enhance proliferation, survival, and cardiac differentiation [40]. An injectable, hybrid hydrogel was created by combining collagen type I with the copolymer oligo(acryloyl carbonate)-poly(ethylene glycol)-oligo(acryloyl carbonate); cultured bone marrow MSCs were then added and the refilled scaffold was tested in a rat MI model (Table 1). Infarcted rats injected with this hybrid hydrogel plus MSCs exhibited an approximately $26 \%$ reduction of the infarct area, a sixfold ventricular wall thickness enhancement, and increased vessel density compared with untreated infarcted rats. 
Table 4 Outcomes in function recovery after myocardial infarction following gelatin and Matrigel scaffold delivery

\begin{tabular}{|c|c|c|c|c|}
\hline Scaffold material & Cell lines and/or other components & Ml model & Main results & References \\
\hline \multirow[t]{5}{*}{ Gelatin } & Fetal rat ventricular cells & Rat & $\begin{array}{l}\text { Scaffold adhered to tissue, presence of blood vessels, } \\
\text { cell to cell linking and spontaneous contraction, no } \\
\text { cardiac function improvements }\end{array}$ & [140] \\
\hline & Erythropoietin & Rabbit & $\begin{array}{l}\text { LV end-systolic and end-diastolic dimensions } \downarrow \text {, LV EF } \uparrow \text {, } \\
\mathrm{FS} \uparrow, \pm \mathrm{d} P / \mathrm{d} t \uparrow \text {, erythrocyte number } \uparrow \text {, hematocrit } \uparrow \text {, infarct } \\
\text { size } \downarrow \text {, fibrosis } \downarrow \text {, infarct border zone capillary density } \uparrow\end{array}$ & [142] \\
\hline & bFGF & Rat & $\begin{array}{l}\text { FS } \uparrow \text {, infarct size } \downarrow \text {, infarcted/non-infarcted wall thickness } \\
\text { ratio } \uparrow, \text { LV expansion index } \downarrow \text {, capillary and arteriolar } \\
\text { density } \uparrow, C M \text { apoptosis } \downarrow\end{array}$ & [143] \\
\hline & $\begin{array}{l}\text { bFGF alone or with human bone } \\
\text { marrow-derived MSCs or human } \\
\text { cardiosphere-derived cells }\end{array}$ & Pig & 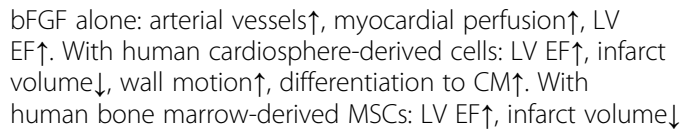 & [144] \\
\hline & $\begin{array}{l}\text { Human cardiac-derived stem } \\
\text { cells+bFGF }\end{array}$ & Human & $\begin{array}{l}\text { No adverse side effects } \uparrow, \text { LV EF } \uparrow \text {, infarct size } \downarrow \text {, maximal } \\
\text { aerobic exercise capacity } \uparrow\end{array}$ & $\begin{array}{l}{[145],} \\
\text { NCT00981006 }\end{array}$ \\
\hline \multirow[t]{7}{*}{ Matrigel } & - & Rat & Capillary density $\uparrow$ & [147] \\
\hline & - & Rat & $\begin{array}{l}\text { LV EF } \uparrow \text {, contractility } \uparrow \text {, infarct wall thickness } \uparrow \text {, angiogenesis } \uparrow \text {, } \\
\text { c-kit+and CD43+ stem cell myocardial homing } \uparrow\end{array}$ & [148] \\
\hline & Rat adipose-derived stromal cells & Rat & LV EF $\uparrow$, LV akinesis $\downarrow$, contractility $\uparrow$, infarcted area size $\downarrow$ & [149] \\
\hline & Mouse ESCs & Mouse & $\begin{array}{l}\text { Connexin } 43 \text { expression, graft/infarct area } \uparrow, F S \uparrow, \text { LV wall } \\
\text { thickness preservation }\end{array}$ & [150] \\
\hline & Mouse ESCs & Rat & $\begin{array}{l}\mathrm{FS} \uparrow \text {, myocardial wall thickness } \uparrow, \text { LV dilatation prevention, } \\
\text { connexin } 43 \text { and a-sarcomeric actin expression }\end{array}$ & [151] \\
\hline & $\begin{array}{l}\text { Human ESC-derived CMs with } \\
\text { prosurvival cocktail }\end{array}$ & Rat & $\begin{array}{l}\text { Cell engraftment } \uparrow, \mathrm{LV} \text { end-diastolic and systolic } \\
\text { dimensions } \downarrow, \mathrm{FS} \uparrow, \mathrm{EF} \uparrow \text {, infarcted area wall thickening }\end{array}$ & [152] \\
\hline & Mouse bone marrow-derived MSCs & Mouse & No improvements in FS, EF, or LV diastolic end volume & [153] \\
\hline \multirow[t]{5}{*}{ Matrigel+collagen } & $\begin{array}{l}\text { Rat H9c2 cardiomyoblasts alone, } \\
\text { with VEGF, or with bFGF }\end{array}$ & Rat & 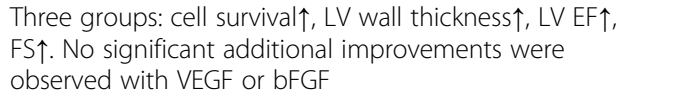 & [154] \\
\hline & Rat myoblasts & Rat & $\begin{array}{l}\text { Inflammatory response } \uparrow, F S \uparrow, \text { LV end-systolic diameter } \downarrow \text {, } \\
\text { scaffold vascularized }\end{array}$ & [155] \\
\hline & Rat cardiac myocytes & Rat & $\begin{array}{l}\text { No improvements in cardiac function or LV wall } \\
\text { thickness, sarcomere integrity, vascularized and } \\
\text { innervated graft, contraction preserved, electrical and } \\
\text { mechanical coupling requires further evaluation }\end{array}$ & [156] \\
\hline & Rat neonatal ventricular CMs & Rat & $\begin{array}{l}\text { CM sarcomeric structural integrity, FS } \uparrow \text {, anterior wall } \\
\text { thickness } \uparrow, \text { LV end-systolic diameter } \downarrow\end{array}$ & [157] \\
\hline & Rat neonatal heart cells & Rat & $\begin{array}{l}\text { Non-delayed electrical coupling, dilatation } \downarrow \text {, systolic wall } \\
\text { thickening } \uparrow, \text { FS area } \uparrow\end{array}$ & [158] \\
\hline
\end{tabular}

bFGF basic fibroblast growth factor, $C M$ cardiomyocyte; $\mathrm{d} P / \mathrm{d} t$ change in pressure over time, $E F$ ejection fraction, ESC embryonic stem cell, $F S$ fractional shortening, $L V$ left ventricle/left ventricular, MI myocardial infarction, MSC mesenchymal stem cell, VEGF vascular endothelial growth factor

Notably, EF values reached those measured prior to MI induction, showing excellent heart function recovery for treated rats [41].

It is important to point out that all the in vivo studies which used collagen scaffolds were performed with type I collagen; thus, the observed differences between the different parameters can not be attributed to the collagen type. It would be interesting to carry out future animal experimentation using other collagen types (that is, collagen type III), evaluating the final outcomes and comparing them with the extensive work done with type I collagen scaffolds.

\section{Fibrin}

Fibrin, a truncated form of fibrinogen, attracts and recruits leukocytes, principally macrophages, to participate in blood clot formation and wound healing processes [42-44], and also plays important roles in cell matrix interactions, inflammatory responses, and neoplasia [42].

Fibrin can be obtained from patient blood, which avoids the risk of adverse immunological responses, and can be easily manipulated by readjusting fibrinogen concentrations and/or polymerization rates to modulate matrix density, mechanical strength, and microstructure [45-49]. Moreover, fibrin scaffolds are good candidates for 
Table 5 Myocardial infarction animal models and the progress in infarction regeneration for decellularized extracellular matrix-based scaffolds

\begin{tabular}{|c|c|c|c|c|}
\hline Scaffold material & $\begin{array}{l}\text { Cell lines and/or other } \\
\text { components }\end{array}$ & $\begin{array}{l}\text { Ml } \\
\text { model }\end{array}$ & Main results & References \\
\hline \multirow[t]{3}{*}{ Decellularized myocardial ECM } & - & Rat & 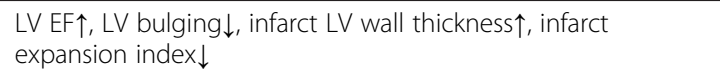 & {$[166]$} \\
\hline & - & Rat & $\begin{array}{l}\text { Viable myocardium islands inside infarcted zone } \uparrow \text {, no } \\
\text { arrhythmia induction, proliferative cell density (mainly } \\
\text { lymphocytes) } \uparrow, E F \text { preservation }\end{array}$ & {$[167]$} \\
\hline & - & $\begin{array}{l}\text { Rat and } \\
\text { pig }\end{array}$ & $\begin{array}{l}\text { Rat: ECM biodegradable and biocompatible with host } \\
\text { myocardium, absence of embolization or ischemia. Pig: } \\
\text { LV EF } \uparrow, \text { LV end diastolic and systolic volumes } \downarrow \text {, contractility } \uparrow \text {, } \\
\text { global wall motion score } \uparrow \text {, proportion of endocardial muscle } \uparrow \text {, } \\
\text { fibrosis } \downarrow \text {, presence of neovascularization, unaltered cardiac } \\
\text { rhythm or blood chemistry }\end{array}$ & {$[168]$} \\
\hline \multirow[t]{4}{*}{ Decellularized pericardium ECM } & Rat bone marrow MSCs & Rat & $\begin{array}{l}\text { LV cavity enlargement prevented, LV FS } \uparrow, \text { LV end } \\
\text { diastolic and systolic pressures improved, no apoptosis, } \\
\text { microvessel density } \uparrow \text {, differentiation to smooth muscle } \\
\text { cells or myofibroblasts, growth factor expression and } \\
\text { cytokine release } \uparrow\end{array}$ & [176] \\
\hline & Rat bone marrow MSCs & Rat & $\begin{array}{l}\text { LV FS } \uparrow, \text { LV end diastolic and systolic pressure } \\
\text { improvements, LV dilatation } \downarrow \text {, absence of apoptosis, } \\
\text { blood vessel density } \uparrow \text {, differentiation into smooth } \\
\text { muscle cells or myofibroblasts }\end{array}$ & [177] \\
\hline & bFGF & Rat & $\begin{array}{l}\text { bFGF retention } \uparrow \text {, arteriole density } \uparrow, \text { confirmation of } \\
\text { vessel functionality }\end{array}$ & [178] \\
\hline & HGF fragment & Rat & $\begin{array}{l}\text { LV remodeling prevention, fractional area change } \uparrow \text {, } \\
\text { arteriole density } \uparrow\end{array}$ & [179] \\
\hline $\begin{array}{l}\text { Decellularized pericardium ECM+ } \\
\text { RAD16-I peptidic hydrogel }\end{array}$ & $\begin{array}{l}\text { Porcine mediastinal } \\
\text { ATDPCs }\end{array}$ & Pig & Infarct size $\downarrow$, vascularization $\uparrow$ & [174] \\
\hline \multirow[t]{3}{*}{ SIS } & - & Mouse & $\begin{array}{l}\text { LV end systolic area } \downarrow \text {, contractility } \uparrow \text {, infarct size } \downarrow \text {, } \\
\text { capillary formation } \uparrow\end{array}$ & [180] \\
\hline & Rabbit MSCs & Rabbit & $\begin{array}{l}\text { LV dimensions improved, anterior wall thickness } \uparrow \text {, } \\
\text { contractility } \uparrow, \mathrm{LV} \text { relaxation } \uparrow \text {, vascular density } \uparrow \text {, no } \\
\text { immunological response, cardiac troponin } T \text { and a- } \\
\text { smooth muscle actin expression }\end{array}$ & [181] \\
\hline & bFGF & Rat & $\begin{array}{l}\text { EF } \uparrow, \text { LV end systolic and diastolic volumes } \downarrow \text {, } \\
\text { contractility } \uparrow\end{array}$ & [182] \\
\hline \multirow[t]{3}{*}{ UBM } & - & Pig & $\begin{array}{l}\text { Smooth muscle cells } \uparrow \text {, myofibroblast recruitment, } \\
\text { inflammation } \downarrow \text {, thrombus extension } \downarrow\end{array}$ & [162] \\
\hline & - & Dog & $\begin{array}{l}\text { Myocyte recruitment with normal morphology and } \\
\text { organization, myocyte proliferation } \uparrow \text {, regional stroke } \\
\text { work } \uparrow \text {, systolic contraction } \uparrow\end{array}$ & [185] \\
\hline & $\begin{array}{l}\text { Human MSCs (spheroid or } \\
\text { non-manipulated) }\end{array}$ & Dog & $\begin{array}{l}\text { Regional stroke work } \uparrow \text {, systolic area contraction } \uparrow \text {, } \\
\text { organized sarcomeric structure }\end{array}$ & [186] \\
\hline
\end{tabular}

ATDPC adipose tissue-derived progenitor cell, $b F G F$ basic fibroblast growth factor, ECM extracellular matrix, EF ejection fraction, $F S$ fractional shortening, $H G F$ hepatocyte growth factor, LV left ventricle/left ventricular, MI myocardial infarction, MSC mesenchymal stem cell, SIS small intestine submucosa, UBM urinary bladder matrix

treating MIs due to their high biocompatibility, biodegradability, and capacity for incorporating different cell types. In addition, fibrin scaffolds can be assembled with either growth factors or other scaffold materials [49-51].

Due to its intrinsic properties, application of a fibrin patch alone (without cells) over the infarcted myocardium exerts beneficial effects (Table 2). In a rat MI model, application of a fibrin glue, which formed a scaffold, reduced the infarct size and increased microvessel formation. Similar results were observed when rat neonatal skeletal myoblasts were mixed with the fibrin glue. However, vessel density was greatest in the fibrinalone group [52, 53]. Fibrin scaffolds have been most frequently used as a cell platform to test delivery of adiposederived MSCs, bone marrow cells, ESC-derived cardiac progenitors, human iPSC-derived ECs, smooth muscle cells and CMs, a native cardiac cell population, umbilical cord blood MSCs, ESCs, and MSCs in different in vivo MI models (Table 2). Results have shown improved preservation of cardiac function post-MI, increased cell retention 
Table 6 Detailed data of clinical trials in progress or completed using different natural scaffolds

\begin{tabular}{|c|c|c|c|c|c|c|}
\hline $\begin{array}{l}\text { Scaffold } \\
\text { material }\end{array}$ & $\begin{array}{l}\text { Study } \\
\text { name }\end{array}$ & $\begin{array}{l}\text { Cell lines and/or } \\
\text { other components }\end{array}$ & State & Follow-up & Main results/objectives & $\begin{array}{l}\text { References/clinical } \\
\text { trial identifier }\end{array}$ \\
\hline Collagen & MAGNUM & $\begin{array}{l}\text { Human mononuclear } \\
\text { bone marrow stem } \\
\text { cells }\end{array}$ & $\begin{array}{l}\text { Completed with } \\
20 \text { patients }\end{array}$ & 10 months & $\begin{array}{l}\text { No adverse related events, } 1 \text { point } \\
\text { reduction of New York Heart } \\
\text { Association functional class, } 26 \% \\
\text { reduction of LV end-diastolic volume, } \\
22 \% \text { improvement of LV filling } \\
\text { deceleration time, } 50 \% \text { increase of } \\
\text { scar thickness, } 26 \% \text { enhancement of EF }\end{array}$ & {$[37,38]$} \\
\hline Fibrin & ESCORT & hESC & $\begin{array}{l}\text { Recruiting } \\
\text { patients }\end{array}$ & - & $\begin{array}{l}\text { Study the number and nature of } \\
\text { adverse events (clinical/biological } \\
\text { abnormalities, arrhythmias and } \\
\text { cardiac or extracardiac tumors). Test } \\
\text { feasibility and efficacy of the scaffold } \\
\text { in cardiac function recovery }\end{array}$ & NCT02057900 \\
\hline Alginate & $\begin{array}{l}\text { AUGMENT- } \\
\text { HF }\end{array}$ & - & $\begin{array}{l}\text { Completed with } \\
6 \text { patients }\end{array}$ & 3 months & $\begin{array}{l}\text { Increase of Kansas City Cardiomyopathy } \\
\text { Questionnaire from } 39.4 \text { to } 74 \text {, number } \\
\text { of patients with New York Heart } \\
\text { Association class III/IV reduced from } 6 \\
\text { to } 1 \text {. No improves in EF and LV end- } \\
\text { diastolic and end-systolic volumes }\end{array}$ & [111] \\
\hline Gelatin & ALCADIA & $\begin{array}{l}\text { Human cardiac- } \\
\text { derived stem } \\
\text { cells+bFGF }\end{array}$ & $\begin{array}{l}\text { Completed with } \\
6 \text { patients }\end{array}$ & 6 months & $\begin{array}{l}12 \% \text { increase in LV EF, } 3.3 \% \text { decrease } \\
\text { of infarct size, maximal aerobic exercise } \\
\text { capacity enhanced by } 4.5 \mathrm{ml} / \mathrm{kg} / \mathrm{min}\end{array}$ & [145], NCT00981006 \\
\hline SIS & - & - & $\begin{array}{l}\text { Enrolling } \\
\text { participants (by } \\
\text { invitation only) }\end{array}$ & - & $\begin{array}{l}\text { Evaluate scaffold safety and beneficial } \\
\text { effects in heart function }\end{array}$ & NCT02139189 \\
\hline
\end{tabular}

bFGF basic fibroblast growth factor, EF ejection fraction, $h E S C$ human embryonic stem cell, $L V$ left ventricle/left ventricular, SIS small intestine submucosa

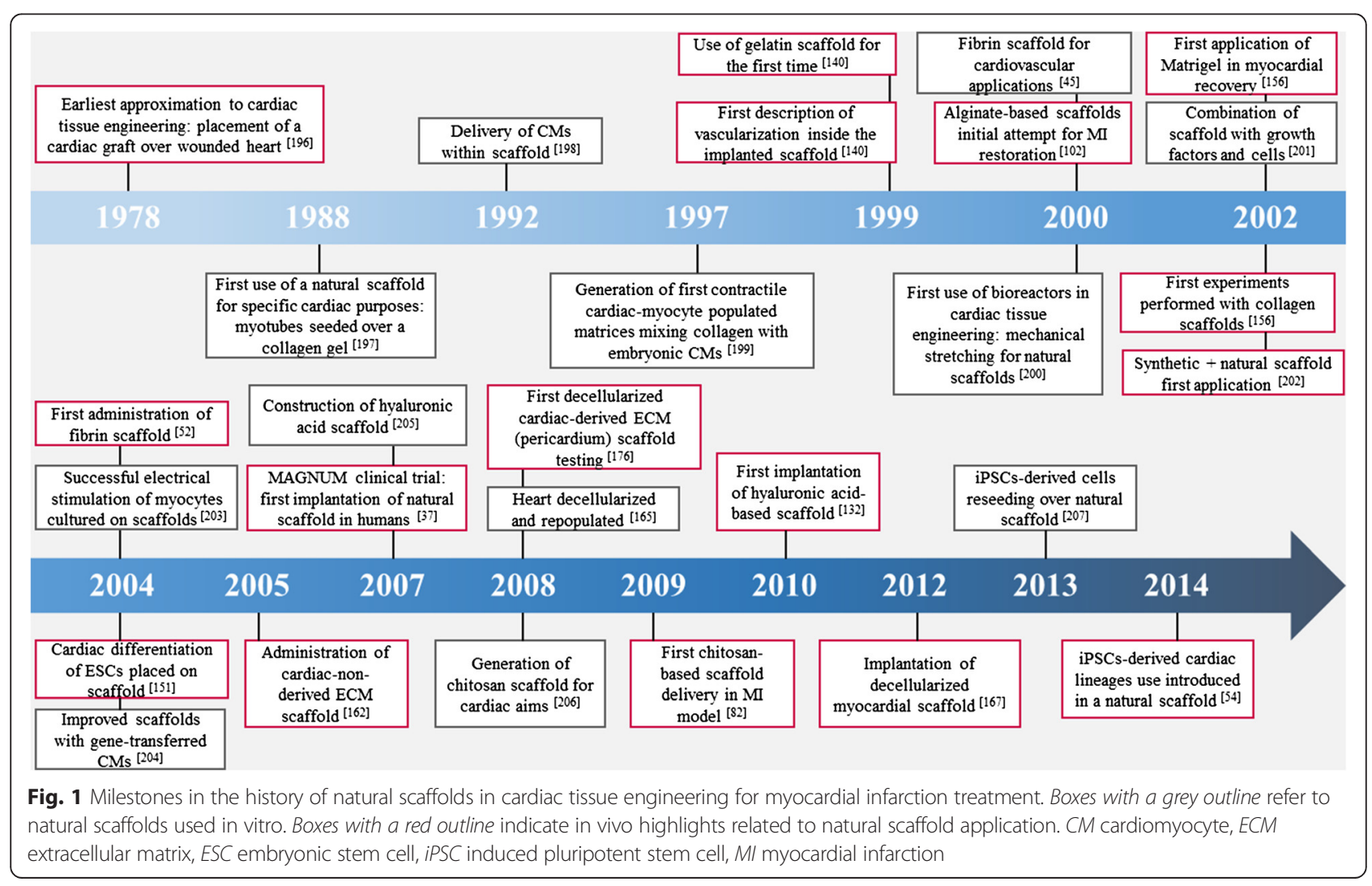



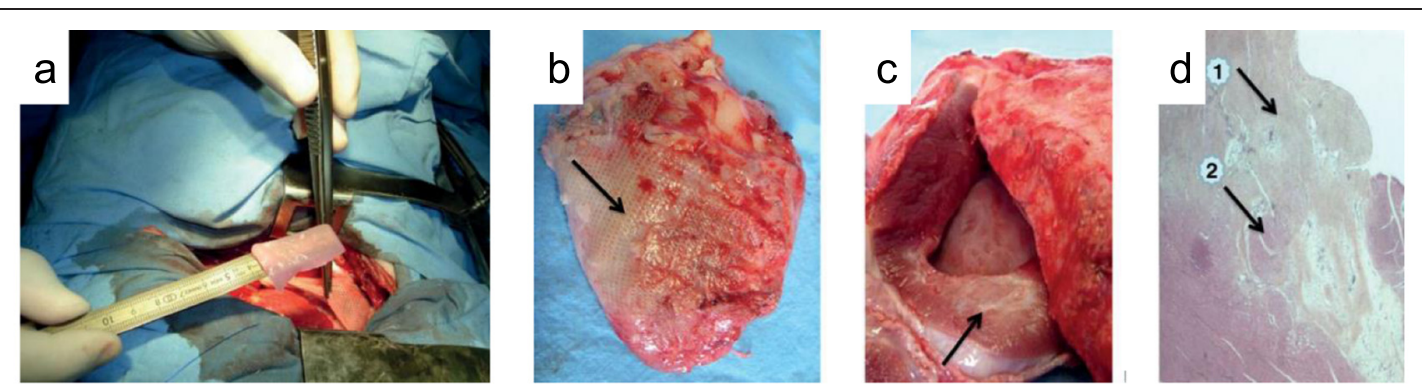

e
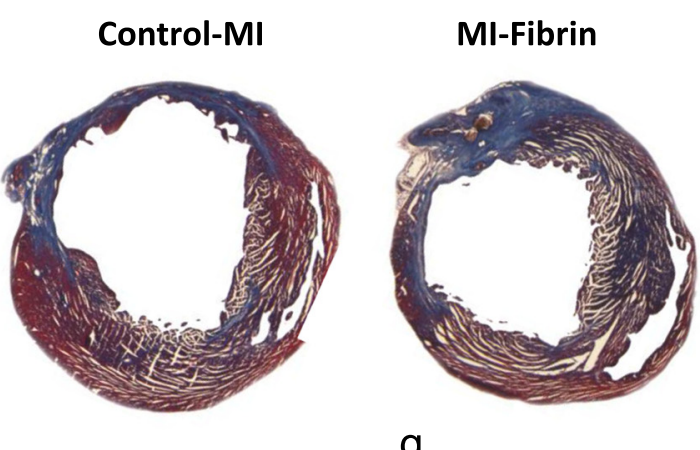

MI-UCBMSCs

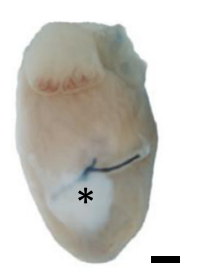

f

g
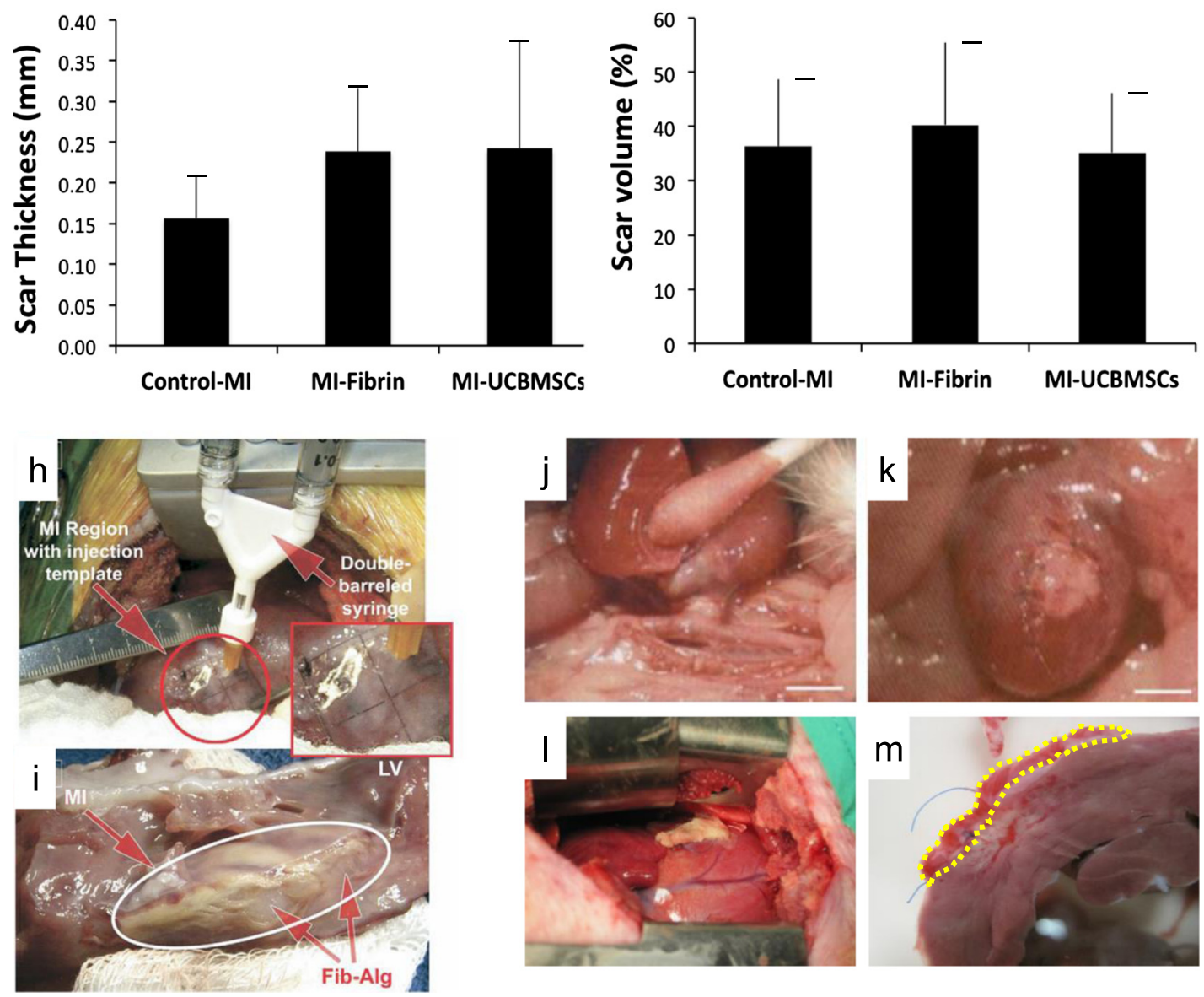

Fig. 2 (See legend on next page.) 
(See figure on previous page.)

Fig. 2 Natural scaffolds for cardiac tissue engineering. Combined surgical procedure using CorCap ventricular constraint device and collagen scaffold implantation in a sheep ischemic model for myocardial repair and ventricular chamber remodeling. a Introduction of the cell-seeded collagen matrix between the heart and the CorCap polyester device (Shafy et al. [32]). b Autopsy at 3 months showing the CorCap mesh covering both ventricles (arrow) (Shafy et al. [32]). c Left ventricular infarct scar (arrow) (Shafy et al. [32]). d Histology at 3 months of the ischemic/reperfused myocardium. Arrows show the mixed configuration: patchy fibrosis (1) and subnormal myocardium (2) (Shafy et al. [32]). a-c Reproduced, with permission, from [32]. e- $\mathbf{g}$ Three-dimensional engineered fibrin-cell patches implanted over infarcted myocardium wounds in mice. e Representative photograph of a mouse heart excised from a post-myocardial infarction (M) animal at 4 weeks post-implantation of an adhesive fibrin-based patch composed of human umbilical cord blood mesenchymal stem cells (UCBMSCs) (asterisk). Images of Masson's trichrome staining of cross-sections from the three groups of post-infarcted animals. Scale bar $=1 \mathrm{~mm}$ (Roura et al. [62]). Histograms represent the percentage of LV scar thickness (f) and volume (g) (Roura et al. [62]). e-g Reproduced, with permission, from [62]. $\mathbf{h}$ Intraoperative injection of the fibrin-alginate composite was performed using a $2 \times 2 \mathrm{~cm}$ template with injection sites arrayed at $0.5 \mathrm{~cm}$ intervals within the region of MI. i At necropsy, the fibrin-alginate (Fib-Alg) could be visualized as amorphous densities within the MI region (LV left ventricle) (Mukherjee et al. [115]); reproduced, with permission, from [115]. j, k Heterotopic heart transplant surgery and hyaluronan-based scaffold (HYAFF $\left.{ }^{\circ} 11\right)$ implantation in the rat MI model. The heart-lung block was carefully excised, the left lung removed, and the cardiac infarction induced by left descending coronary artery ligation on the bench (Fiumana et al. [126]); reproduced, with permission from [126]. $\mathbf{j}$ The allograft was transplanted by end-to-side anastomosis of the aorta to the abdominal aorta of the recipient. Scale bar $=5 \mathrm{~mm}$ (Fiumana et al. [126]). $\mathbf{k}$ The bioengineered HYAFF 11 was introduced into a pouch made in the thickness of the ventricular wall of the heterotopic heart at the level of the post-infarction scar. Scale bar $=5 \mathrm{~mm}$ (Fiumana et al. [126]). I, m Myocardial bioprosthesis implantation in porcine infarcted hearts; reproduced, with permission, from [174]. I A myocardial bioprosthesis, composed by decellularized human pericardium embedded with RAD16-I and mediastinal adipose tissue-derived progenitor cells, was implanted over the ischemic myocardium (Prat-Vidal et al. [174]). $\mathbf{m}$ Transversal heart section of a treated pig with the attached bioprosthesis indicated (dotted yellow line) (Prat-Vidal et al. [174])

and, in some cases, reduced infarct size and enhanced angiogenesis [54-63]. The study by Ye and colleagues [54] used ECs, smooth muscle cells and CMs derived from iPSCs-the first in vivo use of iPSC-derived cell$\mathrm{s}-$ and reported highly improved cardiac function (EF approximately $52 \%$ ) and contractility (thickening fractions of approximately $20 \%$ and approximately $7 \%$ at the border and infarct zone, respectively) compared with infarcted animals without treatment after 4 weeks [54]. Alternatively, fibrin scaffolds were enhanced by thymosin $\beta 4$ encapsulation, which increased cell survival almost threefold, protected against hypoxic conditions, and improved cardiac function and wall thickness measured 28 days after MI [64].

Experiments in rat and non-human primate MI models, where a fibrin patch was applied with human ESC-derived cardiac progenitor cells, have produced convincing data that have led to approval of a first-inhuman clinical trial (Tables 2 and 6) [65]. The study, entitled 'Transplantation of human embryonic stem-cell derived progenitors in severe heart failure (ESCORT)' (NCT02057900), is currently in phase 1 and recruiting participants. Its objective is to investigate the feasibility and safety of fibrin scaffolds combined with cells for treating patients with MI.

In order to increase the intrinsic low fibrin stiffness, fibrin scaffolds can be used in combination with other materials (Table 2) [47]. For example, when fibrin was mixed with the synthetic material poly(ether)urethanepolydimethylsiloxane or with poly (lactide-co-glycolide), in vitro experiments showed that it formed a suitable microenvironment which mimicked native myocardium, enhanced cell proliferation, and contributed to proper cell differentiation towards a cardiac lineage [66, 67].
Also, a hybrid polyethylene glycol/fibrin scaffold was combined with stromal cell-derived factor (SDF)- $1 \alpha$, a key factor in injured myocardium cell mobilization, and administered (without cells) into a mouse MI model [68]. This treatment promoted $\mathrm{c}^{-\mathrm{kit}^{+}}$cell homing and increased EF and fractional shortening (FS), measured at 28 days post-MI. Nevertheless, no angiogenic activity was assessed and no significative reduction of infarct area was observed [68].

In another approach, fibrin scaffold combined with cardiac ECM provided acceptable cell viability, and its administration was feasible [69]. This scaffold was tested in vivo with mesenchymal progenitor cells injected into a nude rat MI model (Table 2). At 28 days after scaffold implantation in the infarcted myocardium, treated rats showed increased angiogenesis and cell migration, and preserved cardiac function compared with untreated animals. Next, the same scaffold was enhanced by preconditioning the MSCs with transforming growth factor (TGF)- $\beta$ [70]. This treatment induced greater cell migration and vasculogenesis compared with MSCs not preconditioned with TGF- $\beta$, but no additional improvements in LV functionality were observed [70]. Therefore, combining fibrin with other materials could adjust the properties of fibrin itself and, to some extent, recreate the local stiffness, composition and fiber network present in the native myocardium, representing a good and plausible possibility for regenerating infarcted myocardium.

\section{Chitosan}

Chitosan, a natural linear polymer obtained by chitin deacetylation, has been widely used for tissue replacement [71-76]. This natural material displays high biocompatibility and biodegradability and has the capacity 
to combine with conductive materials to improve electrical signal transmission and/or with other biomaterials $[77,78]$. Additionally, chitosan was shown to be capable of high growth factor retention and strong cellular receptor adhesion due to its hydrophilicity $[79,80]$; these properties make chitosan a suitable scaffold material for injured myocardial repair.

An in vivo study in a rat MI model also demonstrated that brown ATDSCs differentiated into cardiac lineage cells when applied into the infarcted area inside a chitosan scaffold, as they increased cardiac troponin I and $\mathrm{T}$ and connexin 43 expression (Table 3) [81]. This treatment resulted in improved cardiac function and contractility (better EF, FS and LV end-diastolic pressure), reduced infarct size and fibrotic area, and a remarkable increase in vessel density, measured 28 days after scaffold implantation [81]. Interestingly, ATDSCs partially contributed to this new vessel formation, showing von Willebrand factor- and $\alpha$-smooth muscle actin-positive labeling. Altogether, chitosan plus ATDSCs appears to be a valuable approach for myocardial restoration.

Thermo-sensitive chitosan hydrogel (which polymerizes at body temperature) has been widely used with positive effects (Table 3). A rat MI model was treated with a thermo-sensitive chitosan hydrogel, combined with ESCs, nuclear transferred ESCs, or fertilizationderived ESCs, and exhibited enhanced heart function, increased vascularization in the damaged myocardium, and reduced infarct areas, measured 4 weeks after hydrogel transplantation. Importantly, implanted cells seemed to slightly differentiate towards CMs, smooth muscle cells and ECs [82, 83]. Temperature-sensitive chitosan was also applied, enriched with basic fibroblast growth factor (bFGF), in a rat MI model for 28 days [84]. The results included improved cardiac function, significant reductions in infarct size and fibrotic area (9.27\% and $22.91 \%$, respectively), and 2.7-fold more blood vessels in treated animals compared with controls. Another option is to modify the temperature-responsive chitosan scaffold by adding RoY peptide, a factor involved in cell proliferation, survival, and angiogenesis under hypoxic conditions. This construct exhibited satisfactory post-MI results, including infarct size reduction, angiogenesis promotion, ventricular wall thickness and cardiac function improvement [85].

When mixed with natural materials, chitosan scaffolds acquire other properties that favor cell maturation, adhesion, and scaffold coupling with the host myocardium (Table 3). Several natural materials have been tested with chitosan in cardiac tissue engineering, including myocardial ECM [86], alginate [77, 87], gelatin [88], collagen [89], and silk fibroin [90]. Chitosan mixed with alginate with MSCs was tested in vivo in a rat MI model, where it promoted improved cardiac function, new blood vessel formation, cellular survival, and cell proliferation [77]. Remarkably, the chitosan-alginate scaffold applied alone, without cell incorporation, provided the same beneficial effects in the damaged area after implantation. Of interest, the analysis of biodegradability displayed a low scaffold degradation rate, determined 8 weeks post-administration. However, an alginate-only scaffold provided better results in terms of wall thickness, LV expansion, and cardiac function than the chitosan-alginate scaffold, reducing the beneficial impact of the chitosan-alginate combination [87]. Moreover, despite the variety of possibilities and good results obtained with chitosan scaffolds, it is necessary to evaluate their effects in a large animal MI model to ensure that the described effects can be realized in a large cardiovascular system, similar to human. Therefore, further experimentation is mandatory to obtain satisfactory results combining chitosan with other materials.

\section{Alginate}

Alginate is an anionic linear polysaccharide which can form a hydrogel through ionic crosslinking with divalent cations (mainly $\mathrm{Ca}^{2+}$ ) $[91,92]$. This property also enables incorporation and retention of cells and proteins inside the hydrogel; thus, it can be used as a scaffold for tissue regeneration [93, 94]. Interestingly, the implantation of highly purified alginate, free of protein contaminants, resulted in a complete absence of adverse host immune response $[95,96]$. Moreover, alginate mechanical behavior is easily modifiable by different crosslinking or by changing the molecular weight distribution to match the intrinsic stiffness of host myocardium [97].

Administration of alginate scaffolds alone resulted in significant improvements in cardiac function and increased scar thickness in various MI models, including rat [98], dog [99], and swine [100] (Table 3). Remarkably, alginate application was followed by the total absence of arrhythmias or thrombus formation $[98,100]$ and the replacement of the applied scaffold by connective tissue and myofibroblasts [98]. Pig models have enabled cellfilled scaffolds to be generated and tested in vivo with promising outcomes, including significative decreases in LV dilatation and LV mass, and a $53 \%$ and $34 \%$ increase in scar thickness and wall thickness, respectively [100]. Alginate scaffold hydrophilicity and porosity facilitate the incorporation and retention of cultured CMs on the scaffold (>90\% retention). These retained cells exhibited spontaneous contraction, which indicated that alginate platforms are suitable for cell seeding [101]. In a rat MI model, an alginate scaffold seeded with rat fetal cardiac cells enhanced neovascularization, preserved FS and end diastolic and systolic internal diameters, and promoted the formation of myofibers and cardiac gap junctions, measured 65 days after scaffold implantation [102]. On the other hand, notso-positive results were obtained in vivo with human ESCs 
or embryonic bodies; neither new myocardium formation nor cardiomyogenic differentiation was observed in the implanted scaffold [103]. Additionally, treated animals developed LV dilatation and no ESCs were retained in the scarred area 3 weeks after injection. Nonetheless, the alginate composite did not trigger a deleterious immune response and FS increased by $4 \%$ [103]. So far, fetal cardiac cells appear to be the most suitable cell source to continue investigation with alginate scaffolds.

Alginate scaffolds are typically modified, through integrin-mediated binding, with the addition of an arginine-glycine-aspartate sequence (the RGD peptide) derived from ECM proteins involved in cell adhesion, proliferation, migration, survival, and differentiation [104]. Promising results have been obtained in vivo (Table 3). A rat MI model showed remarkable enhancement of FS, LV dimension, angiogenesis, and LV wall thickness measured 5 weeks post-administration of modified scaffolds [105]. The RGD-alginate scaffold also promoted angiogenesis more effectively than the unmodified alginate scaffold in the animal MI model $(12.6 \pm 2.7$ versus $9.3 \pm 4.2$ arteriole/ $\mathrm{mm}^{2}$, respectively). Although not considered a scaffold, similar effects were described for RGD-alginate microbeads with encapsulated MSCs, evaluated 10 weeks after MI [106]. Nevertheless, in a comparative study, the unmodified scaffolds promoted better LV FS, greater fractional area changes, more attenuation of LV dilatation, a lower LV expansion index, and greater scar thickness increases compared with RGD-modified alginate scaffolds [107]. Thus, further experiments should be performed in vivo to elucidate under what conditions RGD has beneficial effects over unmodified alginate scaffolds and its effectiveness in improving cardiac function in order to determine the added value of RGD introduction.

For cardiac regeneration, alginate scaffolds have also been supplemented with two growth factors, insulin growth factor (IGF)-1, with cytoprotective effects, and hepatocyte growth factor (HGF), which is related to mainly antifibrotic and pro-angiogenic processes [108, 109]. When evaluated 4 weeks after MI, IGF/HGF plus alginate microbeads injected into the infarcted myocardium preserved scar thickness, reduced infarct expansion and fibrosis, enhanced angiogenesis and reduced cell apoptosis (Table 3) [110]. It would be interesting to test different combinations of growth factors with alginate scaffolds to determine whether they improve cardiac recovery post-infarction, and to explore the possibility of synergistic effects.

The ongoing AUGMENT-HF clinical trial (Tables 3 and 6), a first-in-human study, aims to evaluate the effects of alginate injection (Algisyl-LVR) in patients with dilated cardiomyopathy. An early follow-up at 3 months demonstrated the feasibility and safety of the scaffold injection. Cardiac evaluations demonstrated that patients who received treatment tended to show enhanced cardiac function and LV size, but no statistical differences were achieved compared with controls; in addition, treated patients showed significant improvements in quality of life and clinical status [111]. Future measurements at longer post-treatment times are expected to show significant beneficial effects on LV function parameters.

Alginate has been mixed with other biomaterials, including hyaluronic acid [112], gelatin [113], elastin [114], chitosan [77], fibrin [115], synthetic polymers [116], and omentum [117]. However, the effects of these combinations in pre-clinical MI models have not been fully defined in most cases (Table 3). One exception is the alginate plus Matrigel patch, assembled with neonatal rat cardiac cells and a growth factor supplement (IGF-1, vascular endothelial growth factor (VEGF), and SDF-1) [117]. This patch was pre-cultured in rat omentum for 1 week to induce pre-vascularization inside the patch prior to its engraftment into the infarcted area of a MI rat model. Then, 28 days after treatment with the pre-vascularized alginate-Matrigel scaffold, rats showed reduced LV dilatation, enhanced local angiogenesis, mechanical and electrical coupling with the host myocardium, limited LV dilatation, and improved cardiac function, preserving FS and diminishing LV dimensions [117]. In another study, a rat MI model was treated with polypyrrole added to alginate, then evaluated 5 weeks after the MI [118]. These rats exhibited increased angiogenesis and enhanced myofibroblast population recruitment compared with a control group treated with phosphate-buffered saline, and the presence of polymer was confirmed in the infarcted area with a non-associated inflammatory response. However, no functional benefits were assessed, and infarct size remained invariable after treatment, thus limiting its clinical application [118].

\section{Hyaluronic acid}

Hyaluronic acid, a glycosaminoglycan component of the ECM, plays key roles in cell behavior and attachment, wound healing, inflammatory responses, tumor development, and connective tissue joining [119]. In addition to applications in damaged myocardium, hyaluronic acidbased scaffolds have been successfully used for space filling and wound repair, bone and cartilage restoration, nerve and brain regeneration, cell and protein delivery, and soft tissue and smooth muscle repair [120].

The molecular weight of the hyaluronic acid construct highly impacts infarcted myocardium recovery and its beneficial effects on cardiac function because the unit size affects mechanical properties, angiogenic processess, and other effects of the biomaterial itself [121, 122] (Table 3). A comparative study of scaffolds that comprised $50 \mathrm{kDa}, 130 \mathrm{kDa}$, and $170 \mathrm{kDa}$ hyaluronic acid 
units demonstrated that scaffolds composed of $50 \mathrm{kDa}$ units showed the best effects, reducing apoptosis and infarct size from $29.4 \%$ to $3.72 \%$ and increasing ventricular wall thickness fourfold and heart function (LV end-diastolic pressure and Tau-weiss parameter), as analyzed 28 days after therapy [121]. These results were consistent with previous studies that described lower apoptotic rates and higher angiogenic activities with scaffolds composed of low molecular weight hyaluronic acid [122, 123]. Additionally, this study also evaluated the effects of the $50 \mathrm{kDa}$ hyaluronic acid scaffold, alone or loaded with VEGF, on cardiac regeneration in both sub-acute and chronic MI animal models [121]. The effects on myocardial recovery and angiogenesis were similar between groups; therefore, VEGF addition did not act synergistically to achieve a significantly different outcome and hyaluronic acid is responsible for the described cardiac benefits [121].

In some cases, hyaluronic acid scaffolds have been seeded with cells of different lineages, mainly pluripotent stem cells, committed to differentiating into endothelial or cardiomyogenic phenotypes, which would reinforce the proangiogenic and regenerative impact of the scaffold. Taking advantage of hyaluronic acid scaffolds, which promoted high adhesion and proliferation, low apoptosis, paracrine factor gene expression, and regulated cell differentiation [124], experiments were conducted to assess the effectiveness of bone marrow mononuclear cells (BMMNCs) [124, 125] and bone marrow MSCs [126] for treating MI (Table 3). The combined action of the scaffold seeded with rat BMMNCs was tested in a rat MI model [124]. After 28 days, rats that received the scaffold plus BMMNCs exhibited less apoptosis, improved EF and LV internal dimensions, indicators of cardiac function, reduced macrophage and neutrophil infiltration and scar size, and enhanced angiogenesis compared with untreated rats. Interestingly, the BMMNC-seeded hyaluronic acid scaffold also induced better CM survival and cardiac output and smaller scars than an injection of BMMNCs alone or the hyaluronic acid scaffold alone. Furthermore, the hyaluronic acid scaffold promoted BMMNC differentiation towards ECs [124]. These outcomes were confirmed with porcine BMMNCs seeded in hyaluronic acid scaffolds and implanted into infarcted pigs; wall thickness, EF (increased $3.3 \%$ ), LV pressures and volumes and angiogenesis were improved while fibrotic area was reduced compared with untreated animals and animals treated with BMMNCs alone or hyaluronic acid scaffolds alone [125]. Alternatively, when harvested in an esterified hyaluronic acid scaffold, rat bone marrow MSCs promoted an increase in angiogenesis and a reduction in fibrosis in a rat MI model [126]. MSCs of porcine origin were also tested in swine [127]. In that study, the scaffold plus cell treatment induced a lower CD3 inflammatory response, less fibrosis by reducing the total amount of collagen I and III, and less cardiac cell degeneration compared with no treatment or treatment with a similar level of scaffold alone (except for inflammation attenuation) [127]. When bone marrow cells and SDF- $1 \alpha$ were used to fill a methacrylated hyaluronic acid scaffold, bone marrow cell homing into the myocardium was increased approximately 8.5 -fold, a higher value than that exhibited with administration of cells alone [128]. Nevertheless, despite all the data collected for bone marrow MSCs with hyaluronic acid scaffolds, function and other cardiac function parameters were not evaluated. Hence, the favorable results obtained with bone marrow MSC in hyaluronic acid scaffolds need to be corroborated in other studies to confirm these promising outcomes.

Other factors and compounds have been combined with hyaluronic acid scaffolds (Table 3). In one study, a recombinant tissue inhibitor of matrix metalloproteinases (rTIMP), which leads to adverse cardiac remodeling and fibrosis when deleted [129], was attached to the acid hyaluronic scaffold [130]. In infarcted pigs, the rTIMP plus scaffold treatment resulted in higher EF and wall thickness, less ventricular dilatation, reduced remodeling due to metalloproteinase activity, and a $50 \%$ smaller infarcted area compared with untreated animals and compared with animals treated with the scaffold alone [130]. Thus, the addition of rTIMP seems to have had a positive and extra effect on cardiac regeneration postMI. In another study, Gelin-S, a compound that enhances cell adhesion, was attached to the hyaluronic acid scaffold [131]. When applied to infarcted rats, this construct increased EF by $18.2 \%$, FS by $12.3 \%$, and neovascularization and decreased collagen deposition by approximately $50 \%$; however, this treatment was not compared with hyaluronic acid scaffold alone [131]. Finally, methacrylated hyaluronic acid scaffolds with different biomaterial stiffness $(7.7$ and $43 \mathrm{kPa})$ were injected into the infarcted myocardium to evaluate the impact of different mechanical properties on cardiac function and myocardial regeneration. Compared with controls, only the $43 \mathrm{kPa}$ scaffold increased ventricular wall thickness and significantly decreased the infarct area (by approximately $20 \%$ ), although cardiac output and EF remained unchanged [132]. A similar study investigated the same hyaluronic acid scaffolds (approximately $7 \mathrm{kPa}$ and 35 to $40 \mathrm{kPa}$ ) but in the context of low or high scaffold sensitivity to hydrolytic degradation [133]. Eight weeks after treatment, all scaffolds increased vascularization and inflammatory responses, but the ventricular wall thickened with more stable scaffolds, while LV systolic volume decreased with higher stiffness scaffolds. Thus, the results suggested that prolonged 
material stabilization provided the best benefits for myocardial restoration. The finding that optimal results were achieved with stiff scaffolds emphasized the notion that the mechanical properties of scaffolds play an important role in cardiac regeneration [133].

For cardiac repair, several supplementary materials have been combined with hyaluronic acid to improve scaffold properties, including gelatin [134], silk fibroin [135], chitosan plus silk fibroin [136], and butyric acid plus retinoic acid [137] (Table 3). A gelatin plus hyaluronic acid scaffold seeded with cardiosphere-derived cells was evaluated at 3 weeks after MI induction [134]. This construct induced increases in EF (approximately $17 \%$ ), viable tissue, wall thickness, and angiogenesis, enhanced cell survival, and promoted the uncompromised differentiation of cardiosphere-derived cells into endothelial and cardiac lineages compared with untreated animals and animals treated with cardiosphere-derived cells or scaffold alone [134]. Similarly, when silk fibroin plus hyaluronic acid scaffolds populated with bone marrow MSCs were injected into animal MI models, they reduced the LV inner diameter and inflammatory responses, and enhanced FS compared with animals with MI and without treatment [135]. Compared with untreated animals or animals treated with bone marrow MSCs alone, animals receiving the scaffold plus cells also exhibited increases in LV wall thickness, cell survival, alpha myosin heavy chain expression (a cardiac contractility protein), and release of VEGF, bFGF, and HGF paracrine factors. These results indicated that combining scaffold and cells produced synergistic effects [135]. In another study, a rat MI model was treated with chitosan plus silk fibroin plus hyaluronic acid scaffolds without cells [136]. At 8 weeks post-treatment, rats showed improved heart function parameters, increased angiogenesis, and upregulated expression of VEGF, bFGF, and HGF paracrine factors. These results suggested that the scaffold without cell seeding had positive effects on cardiac function, being a suitable scaffold for different cell harvesting and for determining scaffold effects independently of cellular ones [136]. Finally, infarcted pigs were treated with a combination of human placenta-derived MSCs placed in a hyaluronic acid scaffold that had been modified with butyric and retinoic acids [137]. This treatment resulted in increased FS, wall thickness, and blood vessel density compared with phosphate-buffered saline or cellonly treatment. Importantly, the collagen content was reduced after treatment, and scar size and fibrotic area core were reduced by $64 \%$ and $44.6 \%$, respectively. Of interest, this study performed a proteomic analysis of the LV border zone; the group with the implanted scaffold displayed higher proteomic homology (45\%) to the healthy myocardium compared with the other groups, which corroborated the regenerative effects and functional recovery provided by scaffold delivery [137].

\section{Gelatin}

Gelatin is a natural polymer that can be produced from bone, skin, or tendon collagen by partial hydrolysis with acid or alkaline solutions. Gelatin is highly biocompatible and biodegradable, has low antigenicity and can be produced and prepared at relatively low cost [138, 139]. These properties make gelatin ideal for use as a natural scaffold in cardiac tissue engineering.

Despite the small number of in vivo studies that used gelatin scaffolds alone or combined with other materials, some promising results are likely to encourage their future application (Table 4). For example, a gelatin mesh seeded with fetal rat ventricular cells was evaluated 5 weeks after implantation into infarcted rat hearts [140]. This construct showed good engraftment to the host myocardium, and the presence of blood vessels indicated vascularization of the cardiac graft. Furthermore, the cells rearranged to form connections between them, and exhibited spontaneous contractions. However, lack of functional or structural cardiac improvements dissuades further application of this particular combination [140]. The scaffold effects could be enhanced by adding erythropoietin, a glycoprotein hormone used in the treatment of anemia in patients with heart failure, which reduces ventricular hypertrophy and increases EF [141]. In a rabbit MI model, gelatin plus erythropoietin scaffolds were applied 20 minutes after inducing the MI [142]. At 14 days and 2 months after treatment, the treated rabbits displayed reduced LV diastolic and systolic dimensions, infarct size, and fibrosis, and enhanced EF, FS, and capillary density in the infarct border zone. In another study, bFGF was added to gelatin scaffolds for treating a rat MI model [143]. After 2 and 4 weeks of treatment, these animals showed lower $\mathrm{CM}$ apoptotic rates, higher arteriole densities, higher expansion indexes, greater infarcted/non-infarcted wall thickness ratios, and smaller infarct sizes in comparison with untreated animals (except for infarct size, which was only reduced after 2 weeks). Compared with scaffold alone, the scaffold plus bFGF treatment induced, at 2 weeks post-treatment, smaller infarct areas, lower expansion indexes, lower apoptotic rates, and higher arteriole numbers; at 4 weeks, more arterioles and capillaries and less apoptosis were observed [143]. In a pig MI model, bFGF was combined with the gelatin scaffold, with or without either human bone marrow-derived MSCs or human cardiospherederived cells [144]. When the three groups were compared (scaffold plus bFGF, scaffold plus bFGF plus human bone marrow-derived MSCs, and scaffold plus bFGF plus human cardiosphere-derived cells), optimal results were achieved with the combination of scaffold plus bFGF plus human cardiosphere-derived cells, which displayed the highest EF increase (approximately $9 \%$ ) and infarct volume reduction (approximately $3.7 \%$ ), the greatest wall 
motion index variation (approximately $13 \%$ ), and the most differentiation into CMs. Thus, the results confirmed that bFGF and the cells had additive effects [144].

Collectively, the outstanding results obtained with bFGF and MSCs in a gelatin scaffold have led to its implementation in humans. In a phase I clinical trial, ALCADIA (AutoLogous human CArdiac-Derived stem cell to treat Ischemic cArdiomyopathy, NCT00981006), patients with MI were treated with a combination of gelatin hydrogel embedded with human cardiac-derived stem cells and bFGF (Tables 4 and 6). Of six treated patients, one was excluded due to graft occlusion. Of the five remaining patients, only one experienced heart failure worsening. Evaluation after 6 months revealed a $12 \%$ increase in the LV EF, an improvement in maximum aerobic exercise capacity, and a $3.3 \%$ decrease in infarct size [145]. Nevertheless, a larger number of patients and a longer follow-up are required to evaluate treatment effectiveness.

\section{Matrigel}

Matrigel is a biomaterial derived from ECM secreted by Engelbreth-Holm-Swarm mouse sarcoma cells [146]—whose composition has not been fully defined-which resembles and mimics myocardial ECM. Matrigel promoted angiogenesis both in vitro with ECs and in vivo [147]; thus, it appears to be a good candidate biomaterial for constructing a scaffold for cellular support.

Matrigel (without cells) was administered to infarcted myocardium to evaluate its effects on cardiac function and tissue regeneration (Table 4). In a comparative study, fibrin, collagen, or Matrigel was injected into a rat MI model [147]. Matrigel enhanced capillary density but did not improve cardiac function. On top of that, only collagen significantly increased myofibroblast infiltration compared with untreated animals [147]. Conversely, another study injected Matrigel alone into infarcted rats [148]. At 4 weeks after treatment, increases were observed in LV EF (improvement of $22.7 \%$ ), contractility (a $24.5 \%$ enhancement of LV pressure decline), infarct wall thickness, angiogenesis, and recruitment of c-kit ${ }^{+}$ and $\mathrm{CD} 43^{+}$stem cells to the myocardium.

Taking advantage of the described regenerative effects of Matrigel, several studies have mixed Matrigel with different cell types (Table 4). In one study, Matrigel was combined with adipose-derived stromal cells and injected into a rat MI model [149]. At 4 weeks after the MI, treated rats showed increased normalized EF, less LV akinesis, increased heart contractility, and a smaller infarct area. ESCs have also been used extensively. In one study, a mixture of mouse ESC plus Matrigel scaffold improved FS, preserved LV wall thickness, and increased expression of the cardiac gap junction marker connexin 43 in comparison with untreated animals and animals treated with Matrigel alone [150]. Consistent with this study, a Matrigel plus mouse ESC combination was administered to infarcted rats and evaluated 2 weeks post-treatment [151]. Treated rats exhibited increased FS and LV wall thickness and reduced LV dilatation compared with untreated rats. In addition, introduced cells expressed the cardiac markers connexin 43 and $\alpha$ sarcomeric actin. In spite of these results, a comparison between Matrigel alone and Matrigel with cells showed non-significant differences in terms of FS, LV wall thickness, and prevention of LV dilatation, outlining the rle of Matrigel in myocardial restoration [151]. Human ESCderived CMs seeded onto a Matrigel scaffold and supplemented with a prosurvival cocktail were evaluated in a rat MI model [152]. Treated rats showed significantly enhanced cell engraftment in the scarred area compared with Matrigel plus cells alone. Additionally, at 4 weeks after treatment, the prosurvival cocktail complementation also revealed better results with regard to ventricular dilatation, FS, EF, and infarct zone wall thickness [152]. Conversely, when bone marrow-derived MSCs were mixed with Matrigel, only modest results were observed; there was no improvement in FS, EF, or other cardiac function parameters, hampering future research with these cells [153]. To sum up, extensive good results obtained with ESCs could lead next to in vivo testing in a porcine MI model, prior to clinical trials.

In most cases, Matrigel was combined with collagen, the primary structural protein of the ECM (Table 4). When these two compounds were combined with rat cardiomyoblasts, significant improvements were observed regarding cell survival, cardiac function, and LV wall thickness compared with controls and collagenmatrix treated animals [154]. When a growth factor, either VEGF or bFGF, was added to the Matrigel plus collagen scaffold, no other positive cardiac effects were obtained compared with Matrigel plus collagen alone [154]. Nevertheless, modest results were obtained in a similar study that also employed a Matrigel plus collagen cellular scaffold, but filled with myoblasts [155]. In this study, only a significant FS improvement was detected in infarcted rats after 4 weeks of treatment compared with pre-treatment ( $42 \%$ versus $33 \%$ ); no significant effects were observed in other cardiac parameters. Moreover, the group that received the Matrigel plus collagen scaffold displayed a larger adverse immunological response than untreated rats or rats treated with fibrin [155]. In another study, cardiac myocytes were harvested and incorporated into a Matrigel plus collagen scaffold for treating a rat MI model [156]. This treatment did not provide any benefit in terms of heart function or LV wall thickness. Nonetheless, the generated scaffold was able to couple with the host myocardium, preserved contraction and sarcomere integrity, and presented high levels of neovascularization and innervation after 
engraftment. It is important to point out that although connexin 43 and cadherin expression were demonstrated, further investigation is necessary to show complete electrical and mechanical coupling [156]. The addition of CMs to a Matrigel plus collagen scaffold promoted FS and increased anterior wall thickness [157]. Also, at 4 weeks after MI induction, rats that received this treatment maintained sarcomere integrity and structure and exhibited decreased LV end-systolic volume in comparison with untreated infarcted rats or animals treated with either cells or scaffold alone [157]. Administration of neonatal rat heart cells supported by the Matrigel plus collagen scaffold also led to electrical assembly with the myocardium, diminished ventricular dilatation, enhanced ventricular wall thickening, and increased FS area [158]. Data collected suggest that a Matrigel-collagen scaffold combined with cardiomyoblasts or CMs should have a high impact in future investigations.

\section{Decellularized extracellular matrix}

ECM consists of a dynamic blend of structural and functional molecules that are secreted by cells, with a slightly different composition depending on tissue source [159]. This physiological cellular support platform gives cells a suitable microenvironment; it guides cellular proliferation, attachment, differentiation, migration, and viability by providing different signals or cues [160, 161]. Hence, the isolation of an intact ECM would supply cellular support that best matched the native or physiological extracellular environment [18]. For ECM extraction, it is necessary to remove all cellular and nuclear content, in a process called decellularization, and the acellular ECM must maintain its integrity and architecture [3, 162]. Successful tissue decellularization requires the careful selection of physical, chemical, and enzymatic agents that can remove cellular material without disrupting the ECM. Decellularizing agents have variable effects on ECM structure and composition; any negative distortion of the matrix organization or integrity may affect its ability to support cells $[163,164]$. Therefore, maximal cell removal and ECM property retention are mandatory for obtaining optimal ECM for use as a cellular scaffold. Among the essential properties to maintain, correct three-dimensional organization of the ECM helps in proper cell adhesion, differentiation, survival, and integration $[18,160,164]$. Closely related to this, mechanical properties are tightly associated with fiber arrangement and three-dimensional architecture, which in turn affects ECM scaffold coupling with the host myocardium and its synchronous contraction.

To date, many organs and tissues have been completely decellularized, including heart valves, myocardium, pericardium, lung, pancreas, kidney, liver, mammary gland, and nerve $[163,164]$. For cardiac tissue engineering, myocardial ECM possesses the best properties; it can exactly recreate the microenvironment of the native myocardium. Thus, it favors coupling with host cardiac tissue when engrafted in the infarcted zone. The first heart decellularization was performed in 2008 by antegrade coronary perfusion with sodium dodecyl sulfate. The generated acellular organ preserved the primary matrix proteins, vascular architecture, valves, and chambers; when it was seeded with CMs and ECs, the recellularized heart exhibited contraction [165].

Several studies have been performed in vivo using decellularized myocardium ECM scaffolds (Table 5). Local administration of decellularized myocardial ECM was used to treat the infarcted area in a rat MI model [166]. Six weeks after ECM injection, heart function was enhanced through an $8 \%$ elevation in LV EF, a 1.2-fold increase in LV wall thickness, and a 1.3-fold reduction in the infarct expansion index [166]. In another study, similar improvements were achieved with decellularized myocardial ECM application in a rat MI model; the EF was preserved, a higher proportion of viable myocardium was achieved (1.7-fold higher compared with controls), and arrhythmias were completely absent [167]. These results were corroborated when the decellularized myocardial matrix was administered to a porcine MI model [168]. In that case, EF and contractility were enhanced, LV volumes and fibrotic areas were reduced, and the proportion of endothelial muscle was increased. In addition, adverse side effects (ischemia, embolization, and altered heartbeat) were not detected in either pig or rat infarct models. These results ensured that scaffold delivery was a safe procedure; they also demonstrated that the ECM was highly degradable and biocompatible [168]. These promising results may open the door to repopulate decellularized myocardium with cells. A first attempt showed encouraging outcomes for future preclinical applications, even though they used a combination of decellularized myocardial ECM plus fibrin embedded with mesenchymal progenitor cells, and not the matrix alone plus cells [70]. Recently, our group has implanted a combination of decellularized porcine myocardial ECM (previously characterized and successfully recellularized in vitro) refilled with hydrogel and adipose tissue-derived progenitor cells (ATDPCs) in an infarcted porcine MI model [169] (Fig. 3). The scaffold remained in the damaged area 28 days after animals were sacrificed (Fig. 3f). Thus, this alternative scaffold is feasible and may provide new promising results using an acellular myocardial scaffold.

ECM derived from decellularized pericardium has also been widely used as a supportive scaffold for MI regeneration (Table 5). Pericardium ECM is a porous material that facilitates cellular retention and vascularization. It is 

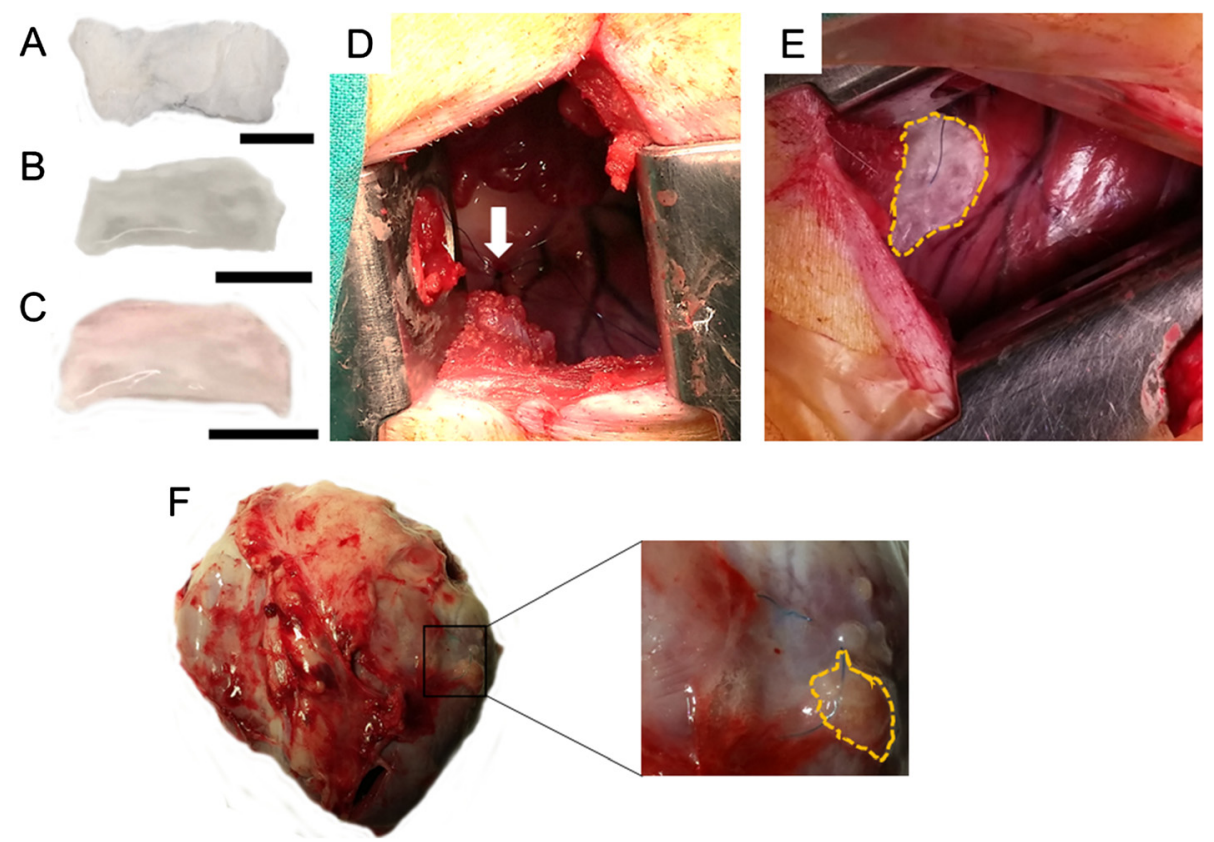

Fig. 3 Engraftment of a decellularized myocardial ECM scaffold embedded with cells in a swine myocardial infarction model. a Lyophilized and gamma ultraviolet sterilized decellularized myocardial ECM scaffold. b, c Decellularized scaffold after the addition of peptide hydrogel (b) and porcine adipose tissue-derived progenitor cells $(\mathbf{c})$. Scale bars $=1 \mathrm{~cm}$. $\mathbf{d}$ Image of the myocardial infarction site, induced by double ligation in the first marginal branch of the circumflex artery (indicated with white arrow). e Reseeded decellularized scaffold placed over the injured myocardium. Scaffold is indicated with yellow dotted lines. $\mathbf{f}$ Presence of the implanted scaffold on the infarcted area in explanted hearts 28 days after sacrifice.

The remaining scaffold is highlighted with yellow dotted lines

easy to perform pericardium resection during surgery and subsequently extract the ECM; moreover, there are no negative consequences [170, 171]. Pericardium properties are comparable among human individuals, and these similar characteristics permit low variability among samples [172]. In vitro results have demonstrated that pericardial ECM seems to resemble myocardial ECM in structure and microenvironment, retain infiltrated cells, and support cardiac differentiation [170, 173-175].

In one in vivo study, rat infarcted myocardium was patched with decellularized pericardium and bone marrow MSCs and evaluated 12 weeks after treatment. The results revealed improvements in LV FS and LV pressures, infarct area vasculogenesis, cardioprotective growth factor and cytokine secretion, and cell differentiation into smooth muscle cells or myofibroblasts [176]. Nearly the same improvements were described when a decellularized pericardium sandwiched between multilayered sheets of bone marrow MSCs was applied to a rat MI model, highlighting functional enhancements in FS and LV pressures [177]. The three-dimensional organization apparently showed correct porosity and pore size, facilitating interconnectivity. Both studies confirm the suitability of MSCs with decellularized pericardial ECM, enabling us to move forward to large animal model experiments. Another study evaluated the synergistic effects of bFGF combined with decellularized pericardium, which displayed well-organized matrix fibers, for treating a rat MI model [178]. After injection, this combination resulted in higher bFGF retention and a $112 \%$ higher number of functional blood vessels in treated rats compared with animals that did not receive bFGF and rats that received collagen alone, decellularized pericardium alone, bFGF alone, or bFGF combined with collagen. An increase in inflammation was observed, but this was attributed to bFGF, not to the decellularized pericardium, because injection of the latter alone did not show significant inflammation compared with saline-injected control groups [178]. When HGF was mixed with decellularized pericardium, treated rats showed significant prevention of LV remodeling, enhanced cardiac function (only fractional area change), and increased arteriole density [179]. Thus, it is imperative to continue investigating the use of growth factors to determine their effectiveness in heart function and structure recovery. Finally, when decellularized pericardium was assembled with RAD-16 peptidic hydrogel and ATDPCs in a swine MI model, infarct size was $36 \%$ reduced and vascularization inside the scaffold was increased. Of note, the scaffold displayed non-disrupted fiber organization and a high in vitro biodegradability, losing about $70 \%$ of the initial weight after 24 hours [174]. 
Other, unrelated cardiac ECMs have been used for cardiac restoration (Table 5). One of these is the acellular ECM derived from porcine small intestinal submucosa (SIS), which is highly biocompatible and mechanically modifiable. Injection of SIS alone in a mouse MI model provided good results: it maintained better LV geometry, reduced the infarcted area, and enhanced contractility and blood vessel density after treatment [180]. In a mouse MI model, treatment with SIS seeded with MSCs improved heart function (EF and LV diastolic and systolic dimensions), contractility, and angiogenesis, and attenuated wall thinning, LV enlargement and adverse immunological responses [181]. Notably, the SIS patch was partially degraded and the cells seeded on it seemed to differentiate into cardiac lineages because they expressed cardiac troponin $\mathrm{T}$ and $\alpha$-smooth muscle actin; however, no connexin 43 expression was detected. This combination was more effective than SIS administration without cells [181]. When SIS was enhanced with bFGF, treated rats displayed higher EF (55.3\% versus $35.1 \%$ ), greater prevention of LV remodeling by reducing LV end-diastolic volumes, and improved heart contraction compared with the untreated group. Of interest, non-enhanced SIS only improved cardiac contractility compared with controls [182]. Currently, a clinical trial (NCT02139189) has begun to recruit participants to test the feasibility and safety of an SIS matrix (also called CorMatrix) for treating damaged myocardium (Tables 5 and 6).

Another non-cardiac-derived ECM widely used is the acellular urinary bladder matrix (UBM; Table 5). Extracted from urinary bladder, it is basically composed of type IV collagen, laminin, and entactin [183]. As a scaffold for cardiac repair, a UBM patch was used to repair an excised portion of the myocardium in a dog model [184]. This treatment enhanced ventricular function compared with a synthetic matrix patch composed of Dacron; additionally, CMs were detected in the UBM patch area, which was not observed with Dacron. In another study in a pig MI model, administration of a UBM patch without cells increased myofibroblast recruitment and the presence of smooth muscle cells, reduced the inflammatory response, and limited thrombus expansion compared with treatment with an expanded polytetrafluoroethylene synthetic biomaterial [162]. Moreover, UBM scaffold was not distinguished from the myocardium. Nevertheless, no improvements in cardiac function, LV dilatation, or contractility were achieved [162]. In a similar study performed in dogs, UBM enhanced regional stroke work and systolic contraction by $3.7 \%$ and $4.4 \%$, respectively [185]. Myocyte recruitment and proliferation, measured 8 weeks after treatment, were also increased. Interestingly, myocyte arrangement in the UBM scaffold was similar to that in the neighboring myocardium [185]. Finally, a comparative study was conducted on UBM patches embedded with either spheroid-derived MSCs or unmanipulated MSCs in a dog MI model [186]. The results revealed that spheroidderived cells provided better heart function and improved contractility, as assessed by regional stroke work, in comparison with unmanipulated MSCs. Myocytes present in the scaffold were correctly rearranged and showed an organized sarcomeric structure [186].

\section{Considerations and future perspectives}

With all the collected data provided by the different studies, it is clear that engrafted scaffolds in the injured heart exert a beneficial effect over myocardium. In spite of not being the main point of this review, it is not fully understood how scaffolds promote the described regenerative effects and which mechanisms follow them. It has been described that a scaffold itself is capable of inducing new blood vessel and nerve fiber formation in swine myocardium, thus facilitating revascularization and reoxygenation of the hypoxic area and electrical coupling [187]. Probably, the local hypoxic environment in the infarcted area induces expression of vascular endothelial and platelet-derived growth factors, SDF- $1 \alpha$, and macrophage chemotactic protein, promoting recruitment of circulating cells to vascularize the affected myocardium in a more favorable microenvironment provided by the scaffold $[187,188]$. The addition of cells helps to reinforce this effect by secreting paracrine factors and synthesizing new endogenous ECM, which in turns mobilizes more cells, favoring myocardial regeneration.

Hence, scaffold biodegradability is a key parameter, as scaffolds should not be degraded quickly after engraftment so they can continue to supply a suitable platform for initial cell administration. However, scaffolds should be easily degradable to allow them to be replaced by the new endogenous matrix synthesized by the administered cells. Moreover, components and molecules derived from degradation have to be non-toxic and absorbable by the body. In the specific case of the natural scaffolds reviewed here, elements derived from degradation are biocompatible and naturally absorbable. In most studies, however, the biodegradability parameter has not been determined. In the work reviewed here, only a few have shown detailed information about scaffold degradation rates, with non-exact quantifications and without clear criteria for determining the degradation rate of the scaffolds [36, 87, 168, 174, 181]. Therefore, further investigation seems to be necessary for discerning the optimal scaffold degradability to accomplish a balance between enough time for enabling initial cell nesting and complete scaffold degradation to allow its proper substitution by newly synthesized cell matrix.

Tightly related to degradability, it is also of particular importance to assess changes in the preserved scaffold 
matrix (if not degraded), or in the new endogenous matrix secreted by implanted cells, which replaces the scaffold. None of the reviewed studies performed an analysis of scaffold elements post-engraftment, which is hard to do as the lack of scaffold or its total integration into the host tissue makes its isolation difficult. Scaffold composition analysis should help us to understand how these changes can affect myocardial regeneration, and how variations in scaffolds can regulate and direct the mechanisms behind these, which could also explain the mechanism by which scaffolds promote cardiac recovery.

Despite the promising results obtained in most preclinical studies, some issues and questions remain unresolved regarding cardiac tissue engineering and the use of natural scaffolds. First, few clinical trials have tested scaffolds with or without cells [37, 38, 111, 145] (NCT00981006, NCT02139189, and NCT02057900; Table 6), which limits the ability to translate procedures from pre-clinical studies to humans. In addition, few studies have been performed in large animal MI models. These animal models could provide more realistic expectations of possible effects in humans, because their cardiovascular systems are more closely related to the human system. It is very important to determine influences on LV function, adverse remodeling, and contractility in a similar cardiovascular system. It is also crucial to investigate inflammatory responses after scaffold injection or engraftment. Because scaffold materials are typically xenogeneic or allogeneic, they might trigger inflammation and macrophage infiltration and this effect must be assessed prior to testing in humans. It is not meaningful to assess inflammatory responses in small animals because they lack human-like inflammatory responses [16]. Additionally, the absence of experimentation in large animal MI models becomes more relevant in applications where the scaffold incorporates cells, because the effects caused by cells may vary among different species. Special caution should be taken with ESCs or iPSCs because they tend to form teratomas; therefore, detailed follow-up should be conducted in large animal MI models before these treatments can be translated to clinical applications [189].

Second, long-term effects must also be evaluated to ensure maintenance of the positive effects provided by the scaffold. A study performed with synthetic scaffolds and myoblasts indicated that heart failure progression could be prevented and high numbers of cells were present after 9 months, but both effects were lost after 12 months [190]. The transitory nature of these effects, albeit using synthetic materials, should motivate new, longer studies to include several time points for evaluating scaffold properties, cell states, and cardiac function.

Finally, although several types of scaffolds and combinations of scaffolds with different cell types have been studied-and in most cases shown promising results-it remains unclear what combination of materials, cells, and growth factors or other supplements might be optimal. Ideally, a scaffold should exactly match the cardiac matrix microenvironment and three-dimensional architecture, which would favor cell attachment, proliferation, and differentiation into cardiomyogenic lineages [17]. Nevertheless, it is highly difficult to achieve this because native cardiac ECM is composed of a mixture of different proteins, glycosaminoglycans, proteoglycans, and growth factors in discrete proportions, which are dispersed in a well-organized structure with a unique three-dimensional architecture [191, 192]. Moreover, the scaffold must mechanically couple with the host myocardium and beat synchronously [17]. Decellularized myocardial ECM could probably best accomplish these conditions, but procuring it requires a decellularization process that might alter its intrinsic properties [164]. The newly emerging technology of bioprinting may facilitate the resolution of these problems. This technique employs a three-dimensional bioprinter to generate a scaffold with a predefined pattern and a well-organized, specified structure. It mixes the selected materials in the chosen proportions and provides control over many parameters, such as porosity [193, 194]. For instance, a three-dimensional bioprinter was used to create small blood vessels from a pre-determined ratio of human adult aortic smooth cells, ECs, and dermal fibroblasts. These vessels were functional and sustained mechanical integrity for up to 28 days [195]. New insights gained over the next few years about ECM structure and composition will inform improvements in bioprinting technology to enable precise selections of elements and distributions based on the native myocardial pattern. This emergent technique may provide a means to achieve the goal of recreating the myocardial ECM.

\section{Conclusion}

Collectively, most recent advances in cardiac tissue engineering using natural scaffolds have shown promising results in myocardial regeneration after MI. These findings should facilitate the development of next-generation scaffolds with enhanced properties, either by adjusting scaffold microenvironments or by delimiting cell choices, thus enabling clinical translation of these newly developed scaffolds. Therefore, natural scaffolds are on the way to be finally implemented as a feasible and alternative MI therapy.

\section{Abbreviations}

ATDPC: Adipose tissue-derived progenitor cells; ATDSC: Adipose tissue-derived stem cells; bFGF: Basic fibroblast growth factor; BMMNC: Bone marrow mononuclear cell; CM: Cardiomyocyte; EC: Endothelial cell; ECM: Extracellular matrix; EF: Ejection fraction; ESC: Embryonic stem cell; FS: Fractional shortening; HGF: Hepatocyte growth factor; IGF: Insulin growth factor; iPSC: Induced pluripotent stem cell; LV: Left ventricle/left ventricular; Ml: Myocardial infarction; MSC: Mesenchymal stem cell; rTIMP: Recombinant tissue inhibitor of matrix metalloproteinases; Sca-1: Stem cell antigen-1; SDF: Stromal cell-derived factor; 
SIS: Small intestine submucosa; TGF: Transforming growth factor; UBM: Urinary bladder matrix; VEGF: Vascular endothelial growth factor; a-MHC: Alpha myosin heavy chain.

\section{Competing interests}

The authors declare that they have no competing interests.

\section{Authors' contributions}

IP-G performed the literature search, designed the manuscript and wrote the first draft of the manuscript. CP-V and AB-G designed the manuscript and participated in the manuscript redaction and correction. All authors read, revised and approved the final manuscript.

\section{Acknowledgements}

This work was supported by the Instituto de Salud Carlos III (Red de Investigación Cardiovascular (RIC; RD12/0042/0047), Red de Investigación en Terapia CelularTerCel (RD12/0019-/0029) and FIS-PI14/01682), Ministerio de Ciencia e Innovación (SAF-2011-30067-C02-01/02 and SAF-2014-59892), Fundació Privada Daniel Bravo Andreu, La Marató de TV3 (12/2232), Medical Sciences and Health Academy of Catalonia and Balearics, the Catalan Society of Cardiology and the Spanish Society of Cardiology.

\section{Author details}

${ }^{1}$ ICREC (Heart Failure and Cardiac Regeneration) Research Lab, Health Sciences Research Institute Germans Trias i Pujol (IGTP). Cardiology Service, Hospital Universitari Germans Trias i Pujol, 08916 Badalona, Barcelona, Spain. ${ }^{2}$ Department of Medicine, Autonomous University of Barcelona (UAB), Barcelona, Spain.

\section{Published online: 06 December 2015}

\section{References}

1. World Health Organization. The top ten causes of death. 2014. http://www.who.int/mediacentre/factsheets/fs310/en/. Accessed 16 Apr 2015

2. Mozaffarian D, Benjamin EJ, Go AS, Arnett DK, Blaha MJ, Cushman M, et al. Heart disease and stroke statistics - 2015 update: a report from the American Heart Association. Circulation. 2015;131:e29-322.

3. Gálvez-Montón C, Prat-Vidal C, Roura S, Soler-Botija C, Bayes-Genis A Update: Innovation in cardiology (IV). Cardiac tissue engineering and the bioartificial heart. Rev Esp Cardiol. 2013;66:391-9.

4. Segers VFM, Lee RT. Stem-cell therapy for cardiac disease. Nature. 2008;451:937-42.

5. Schächinger V, Erbs S, Elsässer A, Haberbosch W, Hambrecht R, Hölschermann $\mathrm{H}$, et al. Intracoronary bone marrow-derived progenitor cells in acute myocardial infarction. N Engl J Med. 2006;355:1210-21.

6. Yamada S, Nelson TJ, Crespo-Diaz RJ, Perez-Terzic C, Liu XK, Miki T, et al. Embryonic stem cell therapy of heart failure in genetic cardiomyopathy. Stem Cells. 2008:26:2644-53.

7. Higuchi T, Miyagawa S, Pearson JT, Fukushima S, Saito A, Tsuchimochi H, et al. Functional and electrical integration of induced pluripotent stem cell-derived cardiomyocytes in a myocardial infarction rat heart. Cell Transplant. 2015 [Epub ahead of print].

8. Amado LC, Saliaris AP, Schuleri KH, St John M, Xie JS, Cattaneo S, et al. Cardiac repair with intramyocardial injection of allogeneic mesenchymal stem cells after myocardial infarction. Proc Natl Acad Sci USA. 2005;102:11474-9.

9. Chen SL, Fang WW, Ye F, Liu YH, Qian J, Shan SJ, et al. Effect on left ventricular function of intracoronary transplantation of autologous bone marrow mesenchymal stem cell in patients with acute myocardial infarction. Am J Cardiol. 2004;94:92-5.

10. Beltrami AP, Barlucchi L, Torella D, Baker M, Limana F, Chimenti S, et al. Adult cardiac stem cells are multipotent and support myocardial regeneration. Cell. 2003;114:763-76.

11. Matsuura K, Honda A, Nagai T, Fukushima N, Iwanaga K, Tokunaga M, et al. Transplantation of cardiac progenitor cells ameliorates cardiac dysfunction after myocardial infarction in mice. J Clin Invest. 2009;119:2204-17.

12. Ye L, Haider HK, Jiang S, Ling LH, Ge R, Law PK, et al. Reversal of myocardial injury using genetically modulated human skeletal myoblasts in a rodent cryoinjured heart model. Eur J Heart Fail. 2005;7:945-52.

13. Yoshioka T, Ageyama N, Shibata H, Yasu T, Misawa Y, Takeuchi K, et al. Repair of infarcted myocardium mediated by transplanted bone marrow-derived CD34+ stem cells in a nonhuman primate model. Stem Cells. 2005;23:355-64.
14. Cai L, Johnstone BH, Cook TG, Tan J, Fishbein MC, Chen PS, et al. IFATS collection: Human adipose tissue-derived stem cells induce angiogenesis and nerve sprouting following myocardial infarction, in conjunction with potent preservation of cardiac function. Stem Cells. 2009;27:230-7.

15. Li TS, Takahashi M, Ohshima M, Qin SL, Kubo M, Muramatsu K, et al. Myocardial repair achieved by the intramyocardial implantation of adult cardiomyocytes in combination with bone marrow cells. Cell Transplant. 2008;17:695-703.

16. Vunjak-Novakovic G, Lui KO, Tandon N, Chien KR. Bioengineering heart muscle: a paradigm for regenerative medicine. Annu Rev Biomed Eng. 2011;13:245-67.

17. Vunjak-Novakovic G, Tandon N, Godier A, Maidhof R, Marsano A, Martens TP, et al. Challenges in cardiac tissue engineering. Tissue Eng Part B Rev. 2010;16:169-87.

18. Sarig U, Machluf M. Engineering cell platforms for myocardial regeneration. Expert Opin Biol Ther. 2011;11:1055-77.

19. Gelse K, Pöschi E, Aigner T. Collagens-structure, function, and biosynthesis. Adv Drug Deliv Rev. 2003;55:1531-46.

20. Xu Y, Dong S, Zhou Q, Mo X, Song L, Hou T, et al. The effect of mechanical stimulation on the maturation of TDSCs-poly(L-lactide-co-e-caprolactone)/ collagen scaffold constructs for tendon tissue engineering. Biomaterials. 2014;35:2760-72.

21. Gautam S, Chou CF, Dinda AK, Potdar PD, Mishra NC. Surface modification of nanofibrous polycaprolactone/gelatin composite scaffold by collagen type I grafting for skin tissue engineering. Mater Sci Eng C Mater Biol Appl. 2014;34:402-9.

22. Tedder ME, Simionescu A, Chen J, Liao J, Simionescu DT. Assembly and testing of stem cell-seeded layered collagen constructs for heart valve tissue engineering. Tissue Eng Part A. 2011;17:25-36.

23. Zhao $Y, X u Y$, Zhang $B$, Wu $X, X u F$, Liang $W$, et al. In vivo generation of thick, vascularized hepatic tissue from collagen hydrogel-based hepatic units. Tissue Eng Part C Methods. 2010;16:653-9.

24. Kijeńska E, Prabhakaran MP, Swieszkowski W, Kurzydlowski KJ, Ramakrishna S. Electrospun bio-composite P(LLA-CL)/collagen I/collagen III scaffolds for nerve tissue engineering. J Biomed Mater Res B Appl Biomater. 2012;100:1093-102.

25. Chiu LL, Reis LA, Momen A, Radisic M. Controlled release of thymosin $\beta 4$ from injected collagen-chitosan hydrogels promotes angiogenesis and prevents tissue loss after myocardial infarction. Regen Med. 2012;7:523-33.

26. Blackburn NJ, Sofrenovic T, Kuraitis D, Ahmadi A, McNeill B, Deng C, et al. Timing underpins the benefits associated with injectable collagen biomaterial therapy for the treatment of myocardial infarction. Biomaterials. 2015;39:182-92.

27. Serpooshan V, Zhao M, Metzler SA, Wei K, Shah PB, Wang A, et al. The effect of bioengineered acellular collagen patch on cardiac remodeling and ventricular function post myocardial infarction. Biomaterials. 2013;34:9048-55.

28. Gaballa MA, Sunkomat JN, Thai H, Morkin E, Ewy G, Goldman S. Grafting an acellular 3-dimensional collagen scaffold onto a non-transmural infarcted myocardium induces neo-angiogenesis and reduces cardiac remodeling. J Heart Lung Transplant. 2006;25:946-54.

29. Holladay CA, Duffy AM, Chen X, Sefton MV, O'Brien TD, Pandit AS. Recovery of cardiac function mediated by MSC and interleukin-10 plasmid functionalised scaffold. Biomaterials. 2012:33:1303-14.

30. Araña M, Peña E, Abizanda G, Cilla M, Ochoa I, Gavira JJ, et al. Preparation and characterization of collagen-based ADSC-carrier sheets for cardiovascular application. Acta Biomater. 2013;9:6075-83.

31. Araña M, Gavira JJ, Peña E, González A, Abizanda G, Cilla M, et al. Epicardial delivery of collagen patches with adipose-derived stem cells in rat and minipig models of chronic myocardial infarction. Biomaterials. 2014;35:143-51.

32. Shafy A, Fink T, Zachar V, Lila N, Carpentier A, Chachques JC. Development of cardiac support bioprostheses for ventricular restoration and myocardial regeneration. Eur J Cardiothorac Surg. 2013;43:1211-9.

33. Mokashi SA, Guan J, Wang D, Tchantchaleishvili V, Brigham M, Lipsitz S, et al. Preventing cardiac remodeling: the combination of cell-based therapy and cardiac support therapy preserves left ventricular function in rodent model of myocardial ischemia. J Thorac Cardiovasc Surg. 2010;140:1374-80.

34. Maureira P, Marie PY, Yu F, Poussier S, Liu Y, Groubatch F, et al. Repairing chronic myocardial infarction with autologous mesenchymal stem cells engineered tissue in rat promotes angiogenesis and limits ventricular remodeling. J Biomed Sci. 2012;19:93.

35. Xiang Z, Liao R, Kelly MS, Spector M. Collagen-GAG scaffolds grafted onto myocardial infarcts in a rat model: a delivery vehicle for mesenchymal stem cells. Tissue Eng. 2006;12:2467-78. 
36. Shi C, Li Q, Zhao Y, Chen W, Chen B, Xiao Z, et al. Stem-cell-capturing collagen scaffold promotes cardiac tissue regeneration. Biomaterials. 2011;32:2508-15.

37. Chachques JC, Trainini JC, Lago N, Masoli OH, Barisani JL, Cortes-Morichetti $M$, et al. Myocardial assistance by grafting a new bioartificial upgraded myocardium (MAGNUM clinical trial): one year follow-up. Cell Transplant. 2007;16:927-34.

38. Chachques JC, Trainini JC, Lago N, Cortes-Morichetti M, Schussler O, Carpentier A. Myocardial Assistance by Grafting a New Bioartificial Upgraded Myocardium (MAGNUM trial): clinical feasibility study. Ann Thorac Surg. 2008;85:901-8.

39. Reis LA, Chiu LL, Wu J, Feric N, Laschinger C, Momen A, et al. Hydrogels with integrin-binding angiopoietin-1-derived peptide, QHREDGS, for treatment of acute myocardial infarction. Circ Heart Fail. 2015;8:333-41.

40. Ravichandran R, Venugopal JR, Sundarrajan S, Mukherjee S, Ramakrishna S. Cardiogenic differentiation of mesenchymal stem cells on elastomeric poly (glycerol sebacate)/collagen core/shell fibers. World J Cardiol. 2013;26:28-41.

41. Xu G, Wang X, Deng C, Teng X, Suuronen EJ, Shen Z, et al. Injectable biodegradable hybrid hydrogels based on thiolated collagen and oligo(acryloyl carbonate)-poly(ethylene glycol)-oligo(acryloyl carbonate) copolymer for functional cardiac regeneration. Acta Biomater. 2015;15:55-64.

42. Mosesson MW, Siebenlist KR, Meh DA. The structure and biological features of fibrinogen and fibrin. Ann N Y Acad Sci. 2001;936:11-30.

43. Ye L, Zimmermann WH, Garry DJ, Zhang J. Patching the heart: cardiac repair from within and outside. Circ Res. 2013;113:922-32.

44. Barsotti MC, Felice F, Balbarini A, Di Stefano R. Fibrin as a scaffold for cardiac tissue engineering. Biotechnol Appl Biochem. 2011;58:301-10.

45. Ye Q, Zünd G, Benedikt P, Jockenhoevel S, Hoerstrup SP, Sakyama S, et al. Fibrin gel as a three dimensional matrix in cardiovascular tissue engineering. Eur J Cardiothorac Surg. 2000;17:587-91.

46. Jockenhoevel S, Zünd G, Hoerstrup SP, Chalabi K, Sachweh JS, Demircan L, et al. Fibrin gel—advantages of a new scaffold in cardiovascular tissue engineering. Eur J Cardiothorac Surg. 2001;19:424-30.

47. Linnes M, Ratner BD, Giachelli CM. A fibrinogen based precision microporous scaffold for tissue engineering. Biomaterials. 2007;28:5298-306.

48. Rowe SL, Lee S, Stegemann JP. Influence of thrombin concentration on the mechanical and morphological properties of cell-seeded fibrin hydrogels. Acta Biomater. 2007;3:59-67.

49. Wiesel JW. Structure of fibrin: impact on clot stability. J Thromb Haemost. 2007:5:116-24

50. Ahmed TAE, Dare EV, Hincke M. Fibrin: a versatile scaffold for tissue engineering applications. Tissue Eng Part B Rev. 2008;14:199-215.

51. Bensaïd W, Triffitt JT, Blanchat C, Oudina K, Sedel L, Petite H. A biodegradable fibrin scaffold for mesenchymal stem cell transplantation. Biomaterials. 2003;24:2497-502.

52. Christman KL, Fok HH, Sievers RE, Fang Q, Lee RJ. Fibrin glue alone and skeletal myoblasts in a fibrin scaffold preserve cardiac function after myocardial infarction. Tissue Eng. 2004;10:403-9.

53. Christman KL, Vardanian AJ, Fang Q, Sievers RE, Fok HH, Lee RJ. Injectable fibrin scaffold improves cell transplant survival, reduces infarct expansion, and induces neovasculature formation in ischemic formation. JACC. 2004;44:654-60.

54. Ye L, Chang YH, Xiong Q, Zhang P, Zhang L, Somasundaram P, et al. Cardiac repair in a porcine model of acute myocardial infarction with human induced pluripotent stem cell-derived cardiovascular cells. Cell Stem Cell. 2014;15:750-61.

55. Bagó JR, Soler-Botija C, Casani L, Aguilar E, Alieva M, Rubio N, et al. Bioluminescence imaging of cardiomyogenic and vascular differentiation of cardiac and subcutaneous adipose tissue-derived progenitor cells in fibrin patches in a myocardium infarct model. Int J Cardiol. 2013;169:288-95.

56. Nakamuta JS, Danoviz ME, Marques FLN, dos Santos L, Becker C, Gonçalves GA, et al. Cell therapy attenuates cardiac dysfunction post myocardial infarction: effect of timing, routes of injection and a fibrin scaffold. PLoS One. 2009;4:e6005.

57. Xiong Q, Hill KL, Li Q, Suntharalingam P, Mansoor A, Wang X, et al. A fibrin patch-based enhanced delivery of human embryonic stem cell-derived vascular cell transplantation in a porcine model of postinfarction LV remodeling. Stem Cells. 2011;29:367-75.

58. Sun CK, Zhen YY, Leu S, Tsai TH, Chang LT, Sheu JJ, et al. Direct implantation versus platelet-rich fibrin-embedded adipose-derived mesenchymal stem cells in treating rat acute myocardial infarction. Int J Cardiol. 2014;173:410-23.

59. Bellamy V, Vanneaux V, Bel A, Nemetalla H, Emmanuelle Boitard S, Farouz Y, et al. Long-term functional benefits of human embryonic stem cell-derived cardiac progenitors embedded into a fibrin scaffold. J Heart Lung Transplant. 2014. doi:10.1016/j.healun.2014.10.008.
60. Wendel JS, Ye L, Zhang P, Tranquillo RT, Zhang JJ. Functional consequences of a tissue-engineered myocardial patch for cardiac repair in a rat infarct model. Tissue Eng Part A. 2014;20:1325-35.

61. Roura S, Bagó JR, Soler-Botija C, Pujal JM, Gálvez-Montón C, Prat-Vidal C, et al. Human umbilical cord blood-derived mesenchymal stem cells promote vascular growth in vivo. PLoS One. 2012;7:e49447.

62. Roura S, Soler-Botija C, Bagó JR, Llucià-Valldeperas A, Fernández M, GálvezMontón C, et al. Post-infarction functional recovery driven by a threedimensional engineered fibrin patch comprised of human umbilical cord blood-derived mesenchymal stem cells. Stem Cells Transl Med. 2015. In press.

63. Liu J, Hu Q, Wang Z, Xu C, Wang X, Gong G, et al. Autologous stem cell transplantation for myocardial repair. Am J Physiol Heart Circ Physiol. 2004; 287:H501-11.

64. Ye L, Zhang P, Duval S, Su L, Xiong Q, Zhang J. Thymosin $\beta 4$ increases the potency of transplanted mesenchymal cells for myocardial repair. Circulation. 2013;128:S32-41.

65. Menasché P, Vanneaux V, Fabreguettes JR, Bel A, Tosca L, Garcia S, et al. Towards a clinical use of human embryonic stem cell-derived cardiac progenitors: a translational experience. Eur Heart J. 2015;36:743-50.

66. Lisi A, Briganti E, Ledda M, Losi P, Grimaldi S, Marchese R, et al. A combined synthetic-fibrin scaffold supports growth and cardiomyogenic commitment of human placental derived stem cells. PLoS One. 2012;7:e34284.

67. Sreerekha PR, Menon D, Nair SV, Chennazhi KP. Fabrication of electrospun poly (lactide-co-glycolide)-fibrin multiscale scaffold for myocardial regeneration in vitro. Tissue Eng Part A. 2013;19:849-59.

68. Zhang G, Nakamura Y, Wang X, Hu Q, Suggs LJ, Zhang J. Controlled release of stromal cell-derived factor-1alpha in situ increases c-kit + cell homing to the infarcted heart. Tissue Eng. 2007;13:2063-71.

69. Williams C, Budina E, Stoppel WL, Sullivan KE, Emani S, Emani SM, et al. Cardiac extracellular matrix-fibrin hybrid scaffolds with tuneable properties for cardiovascular tissue engineering. Acta Biomaterialia. 2015;14:84-95.

70. Godier-Furnémont AFG, Martens TP, Koeckert MS, Wan L, Parks J, Arai K, et al. Composite scaffold provides a cell delivery platform for cardiovascular repair. Proc Natl Acad Sci U S A. 2011;108:7974-9.

71. Revi D, Paul W, Anilkumar TV, Sharma CP. Chitosan scaffold co-cultured with keratinocyte and fibroblast heals full thickness skin wounds in rabbit. J Biomed Mater Res A. 2014;102:3273-81.

72. Guzmán R, Nardecchia S, Gutiérrez MC, Ferrer ML, Ramos V, del Monte F, et al. Chitosan scaffolds containing calcium phosphate salts and rhBMP-2: in vitro and in vivo testing for bone tissue regeneration. PLoS One. 2014. doi:10.1371/journal.pone.0087149.

73. Gao J, Liu R, Wu J, Liu Z, Li J, Zhou J, et al. The use of chitosan based hydrogel for enhancing the therapeutic benefits of adipose-derived MSCS for acute kidney injury. Biomaterials. 2012;33:3673-81.

74. Feng ZQ, Chu X, Huang NP, Wang T, Wang Y, Shi $X$, et al. The effect of nanofibrous galactosylated chitosan scaffolds on the formation of rat primary hepatocyte aggregates and the maintenance of liver function. Biomaterials. 2009;30:2753-63.

75. Xiao W, Hu XY, Zeng W, Huang JH, Luo ZZJ. Rapid sciatic nerve regeneration of rats by a surface modified collagen-chitosan scaffold. Injury. 2013:44:941-6.

76. Liu Z, Wang H, Wang Y, Lin Q, Yao A, Cao F, et al. The influence of chitosan hydrogel on stem cell engraftment, survival and homing in the ischemic myocardial microenvironment. Biomaterials. 2012;33:3093-106.

77. Ceccaldi C, Bushkalova R, Alfarano C, Lairez O, Calise D, Bourin P, et al. Evaluation of polyelectrolyte complex-based scaffolds for mesenchymal stem cell therapy in cardiac ischemia treatment. Acta Biomater. 2014;10:901-11.

78. Martins AM, Eng G, Caridade SG, Mano JF, Reis RL, Vunjak-Novakovic G. Electrically conductive chitosan/carbon scaffolds for cardiac tissue engineering. Biomacromolecules. 2014;15:635-43.

79. Tsuchiya N, Sato S, Kigami R, Kawano E, Takane M, Arai Y, et al. Effect of a chitosan sponge impregnated with platelet-derived growth factor on bone augmentation beyond the skeletal envelope in rat calvaria. J Oral Sci. 2014;56:23-8.

80. Hussain A, Collins G, Yip D, Cho CH. Functional 3-D cardiac co-culture model using bioactive chitosan nanofiber scaffolds. Biotechnol Bioeng. 2013;110:637-47

81. Wang H, Shi J, Wang Y, Yin Y, Wang L, Liu J, et al. Promotion of cardiac differentiation of brown adipose derived stem cells by chitosan hydrogel for repair after myocardial infarction. Biomaterials. 2014;35:3986-98.

82. Lu WN, Lü SH, Wang HB, Li DX, Duan CM, Liu ZQ, et al. Functional improvement of infarcted heart by co-injection of embryonic stem cells 
with temperature-responsive chitosan hydrogel. Tissue Eng Part A. 2009;15:1437-47.

83. Lu S, Wang H, Lu W, Liu S, Lin Q, Li D, et al. Both the transplantation of somatic cell nuclear transfer- and fertilization-derived mouse embryonic stem cells with temperature-responsive chitosan hydrogel improve myocardial performance in infarcted rat hearts. Tissue Eng Part A. 2010;16:1303-15.

84. Wang H, Zhang X, Li Y, Ma Y, Zhang Y, Liu Z, et al. Improved myocardial performance in infarcted rat heart by co-injection of basic fibroblast growth factor with temperature-responsive chitosan hydrogel. J Heart Lung Transplant. 2010:29:881-7

85. Shu Y, Hao T, Yao F, Qian Y, Wang Y, Yang B, et al. RoY peptide-modified chitosan-based hydrogel to improve angiogenesis and cardiac repair under hypoxia. ACS Appl Mater Interfaces. 2015;7:6505-17.

86. Pok S, Benavides OM, Hallal P, Jacot JG. Use of myocardial matrix in a chitosanbased full-thickness heart patch. Tissue Eng Part A. 2014;20:1877-87.

87. Deng $B$, Shen $L, W u Y$, Shen $Y$, Ding $X$, Lu S, et al. Delivery of alginate-chitosan hydrogel promotes endogenous repair and preserves cardiac function in rats with myocardial infarction. J Biomed Mater Res A. 2015;103:907-18.

88. Pok S, Myers JD, Madihally SV, Jacot JG. A multi-layered scaffold of a chitosan and gelatin hydrogel supported by a PCL core for cardiac tissue engineering. Acta Biomater. 2013;9:5630-42.

89. Chiu LL, Janic K, Radisic M. Engineering of oriented myocardium on threedimensional micropatterned collagen-chitosan hydrogel. Int J Artif Organs. 2012;35:237-50

90. Yang MC, Wang SS, Chou NK, Chi NH, Huang YY, Chang YL, et al. The cardiomyogenic differentiation of rat mesenchymal stem cells on silk fibroin-polysaccharide cardiac patches in vitro. Biomaterials. 2009:30:3757-65.

91. Bidarra SJ, Barrias CC, Granja PL. Injectable alginate hydrogels for cell delivery in tissue engineering. Acta Biomater. 2014;10:1646-62.

92. Wee S, Gombotz WR. Protein release from alginate matrices. Adv Drug Deliv Rev. 1998;4:267-85.

93. Moshaverinia A, Xu X, Chen C, Akiyama K, Snead ML, Shi S. Dental mesenchymal stem cells encapsulated in an alginate hydrogel co-delivery microencapsulation system for cartilage regeneration. Acta Biomater. 2013:9:9343-50

94. Wang L, Shansky J, Borselli C, Mooney D, Vandenburgh D. Design and fabrication of a biodegradable, covalently crosslinked shape-memory alginate scaffold for cell and growth factor delivery. Tissue Eng Part A. 2012;18:2000-7.

95. Ménard M, Dusseault J, Langlois G, Baille WE, Tam SK, Yahia L'H, et al. Role of protein contaminants in the immunogenicity of alginates. J Biomed Mater Res B Appl Biomater. 2010;93:333-40.

96. Orive G, Ponce S, Hernández RM, Gascón AR, Igartua M, Pedraz JL. Biocompatibility of microcapsules for cell immobilization elaborated with different type of alginates. Biomaterials. 2002;23:3825-31.

97. Augst $A D$, Kong $H J$, Mooney DJ. Alginate hydrogels as biomaterials. Macromol Biosci. 2006;7:623-33.

98. Landa N, Miller L, Feinberg MS, Holbova R, Shachar M, Freeman I, et al, Effect of injectable alginate implant on cardiac remodeling and function after recent and old infarcts in rat. Circulation. 2008;117:1388-96.

99. Sabbah HN, Wang M, Gupta RC, Rastogi S, Ilsar I, Sabbah MS, et al. Augmentation of left ventricular wall thickness with alginate hydrogel implants improves left ventricular function and prevents progressive remodeling in dogs with chronic heart failure. JACC Heart Fail. 2013;1:252-8.

100. Leor J, Tuvia S, Guetta V, Manczur F, Castel D, Willenz U, et al. Intracoronary injection of in situ forming alginate hydrogel reverses left ventricular remodeling after myocardial infarction in swine. J Am Coll Cardiol. 2009:8:1014-23.

101. Dar A, Shachar M, Leor J, Cohen S. Optimization of cardiac cell seeding and distribution in 3D porous alginate scaffolds. Biotechnol Bioeng. 2002;80:305-12.

102. Leor J, Aboulafia-Etzion S, Dar A, Shapiro L, Barbash IM, Battler A, et al. Bioengineered cardiac grafts: a new approach to repair the infarcted myocardium? Circulation. 2000;102:11156-61.

103. Leor J, Gerecht S, Cohen S, Miller L, Holbova R, Ziskind A, et al. Human embryonic stem cell transplantation to repair the infarcted myocardium. Heart. 2007;93:1278-84

104. Ruoslahti E. RGD and other recognition sequences for integrins. Annu Rev Cell Dev Biol. 1996;12:697-715.

105. Yu J, Gu Y, Du KT, Mihardja S, Sievers RE, Lee RJ. The effect of injected RGD modified alginate on angiogenesis and left ventricular function in chronic rat infarct model. Biomaterials. 2009:30:751-6.
106. Yu J, Du KT, Fang Q, Gu Y, Mihardja SS, Sievers RE, et al. The use of human mesenchymal stem cells encapsulated in RGD modified alginate microspheres in the repair of myocardial infarction in the rat. Biomaterials. 2010;31:7012-20.

107. Tsur-Gang O, Ruvinov E, Landa N, Holbova R, Feinberg MS, Leor J, et al. The effects of peptide-based modification of alginate on left ventricular remodeling and function after acute myocardial infarction. Biomaterials. 2009;30:189-95.

108. Li Q, Li B, Wang X, Leri A, Jana KP, Liu Y, et al. Overexpression of insulin-like growth factor-1 in mice protects from myocyte death after infarction, attenuating ventricular dilatation, wall stress, and cardiac hypertrophy. J Clin Invest. 1999;100:1991-9.

109. Wang Y, Ahmad N, Wani MA, Ashraf M. Hepatocyte growth factor prevents ventricular remodeling and dysfunction in mice via Akt pathway and angiogenesis. J Mol Cell Cardiol. 2004;37:1041-52.

110. Ruvinov E, Leor J, Cohen S. The promotion of myocardial repair by the sequential delivery of IGF-1 and HGF from an injectable alginate biomaterial in a model of acute myocardial infarction. Biomaterials. 2011;32:565-78.

111. Lee RJ, Hinson A, Helgerson A, Bauernschmitt R, Sabbah HN. Polymer-based restoration of left ventricular mechanics. Cell Transplant. 2013;22:529-33.

112. Dahlmann J, Krause A, Möller L, Kensah G, Möwes M, Diekmann A, et al. Fully defined in situ cross-linkable alginate and hyaluronic acid hydrogels for myocardial tissue engineering. Biomaterials. 2013;34:940-51.

113. Rosellini E, Cristallini C, Barbani N, Vozzi G, Giusti P. Preparation and characterization of alginate/gelatin blend films for cardiac tissue engineering. J Biomed Mater Res A. 2009;91:447-53.

114. Chandy T, Rao GH, Wilson RF, Das GS. The development of porous alginate/ elastin/PEG composite matrix for cardiovascular engineering. J Biomater Appl. 2003;17:287-301.

115. Mukherjee R, Zavadzkas JA, Saunders SM, McLean JE, Jeffords LB, Beck C, et al. Targeted myocardial microinjections of a biocomposite material reduces infarct expansion in pigs. Ann Thorac Surg. 2008;86:1268-76.

116. Gnanaprakasam Thankam F, Muthu J, Sankar V, Kozhiparambil GR. Growth and survival of cells in biosynthetic poly vinyl alcohol-alginate IPN hydrogels for cardiac applications. Colloids Surf B Biointerfaces. 2013;107:137-45.

117. Dvir T, Kedem A, Ruvinov E, Levy O, Freeman I, Landa N, et al. Prevascularization of cardiac patch on the omentum improves its therapeutic outcome. Prot Natl Acad Sci U S A. 2009;106:14990-5.

118. Mihardja SS, Sievers RE, Lee RJ. The effect of polypyrrole on arteriogenesis in an acute rat infarct model. Biomaterials. 2008;29:4205-10.

119. Toole BP. Hyaluronan: from extracellular glue to pericellular cue. Nat Rev Cancer. 2004:4:528-39.

120. Collins MN, Birkinshaw C. Hyaluronic acid based scaffolds for tissue engineering - a review. Carbohydr Polym. 2013;92:1262-79.

121. Yoon SJ, Hong S, Fang YH, Song M, Son KH, Son HS, et al. Differential regeneration of myocardial infarction depending on the progression of disease and the composition of biomimetic hydrogel. J Biosci Bioeng. 2014; 118:461-8.

122. Slevin M, Kumar S, Gaffney J. Angiogenic oligosaccharides of hyaluronan induce multiple signaling pathways affecting vascular endothelial cell mitogenic and wound healing responses. J Biol Chem. 2002;277:41046-59.

123. Wolf D, Schümann J, Koerber K, Kiemer AK, Vollmar AM, Sass G, et al. Lowmolecular-weight hyaluronic acid induces nuclear factor-kappaBdependent resistance against tumor necrosis factor alpha-mediated liver injury in mice. Hepatology. 2001;34:535-47.

124. Chen CH, Wang SS, Wei El, Chu TY, Hsieh PC. Hyaluronan enhances bone marrow cell therapy for myocardial repair after infarction. Mol Ther. 2013;21:670-9.

125. Chen $\mathrm{CH}$, Chang MY, Wang SS, Hsieh PC. Injection of autologous bone marrow cells in hyaluronan hydrogel improves cardiac performance after infarction in pigs. Am J Physiol Heart Circ Physiol. 2014;306:H1078-86.

126. Fiumana E, Pasquinelli G, Foroni L, Carboni M, Bonafé F, Orrico C, et al. Localization of mesenchymal stem cells grafted with a hyaluronan-based scaffold in the infarcted heart. J Surg Res. 2013;179:e21-9.

127. Muscari C, Bonafè F, Martin-Suarez S, Valgimigli S, Valente S, Fiumana E, et al. Restored perfusión and reduced inflammation in the infarcted heart after grafting stem cells with a hyaluronian-based scaffold. J Cell Mol Med. 2013;17:518-30.

128. Purcell BP, Elser JA, Mu A, Margulies KB, Burdick JA. Synergistic effects of SDF-1a chemokine and hyaluronic acid release from degradable hydrogels on directing bone marrow derived cell homing to the myocardium. Biomaterials. 2012:33:7849-57. 
129. Kassiri Z, Defamie V, Hariri M, Oudit GY, Anthwal S, Dawood F, et al. Simultaneous transforming growth factor-tumor necrosis factor activation and cross-talk cause aberrant remodeling response and myocardial fibrosis in Timp3-deficient heart. J Biol Chem. 2009;284:29893-904.

130. Eckhouse SR, Purcell BP, McGarvey JR, Lobb D, Logdon CB, Doviak H, et al. Local hydrogel release of recombinant TIMP-3 attenuates adverse left ventricular remodeling after experimental myocardial infarction. Sci Transl Med. 2014. doi:10.1126/scitransImed.3007244

131. Abdalla S, Makhoul G, Duong M, Chiu RC, Cecere R. Hyaluronic acid-based hydrogel induces neovascularization and improves cardiac function in a rat model of myocardial infarction. Interact Cardiovasc Thorac Surg. 2013;17:767-72.

132. Ifkovits JL, Tous E, Minakawa M, Morita M, Robb JD, Koomalsingh KJ, et al. Injectable hydrogel properties influence infarct expansion and extent of postinfarction left ventricular remodeling in an ovine model. Proc Natl Acad Sci U S A. 2010;107:11507-12.

133. Tous E, Ifkovits JL, Koomalsingh KJ, Shuto T, Soeda T, Kondo N, et al. Influence of injectable hyaluronic acid hydrogel degradation behavior on infarction-induced ventricular remodeling. Biomacromolecules. 2011;12:4127-35.

134. Cheng K, Blusztajn A, Shen D, Li TS, Sun B, Galang G, et al. Functional performance of human cardiosphere-derived cells delivered in an in situ polymerizable hyaluronan-gelatin hydrogel. Biomaterials. 2012;33:5317-24.

135. Chi NH, Yang MC, Chung TW, Chen JY, Chou NK, Wang SS. Cardiac repair achieved by bone marrow mesenchymal stem cells/silk fibroin/hyaluronic acid patches in a rat of myocardial infarction model. Biomaterials. 2012;33:5541-51.

136. Chi NH, Yang MC, Chung TW, Chou NK, Wang SS. Cardiac repair using chitosan-hyaluronan/silk fibroin patches in a rat heart model with myocardial infarction. Carbohydr Polym. 2013;92:591-7.

137. Simioniuc A, Campan M, Lionetti V, Marinelli M, Aquaro GD, Cavallini C, et al. Placental stem cells pre-treated with a hyaluronan mixed ester of butyric and retinoic acid to cure infarcted pig hearts: a multimodal study. Cardiovasc Res. 2011;90:546-56.

138. Elzoghby AO. Gelatin-based nanoparticles as drug and gene delivery systems: reviewing three decades of research. J Control Release. 2013;172:1075-91.

139. Van Vlierberghe S, Dubruel P, Schacht E. Biopolymer-based hydrogels as scaffolds for tissue engineering applications: a review. Biomacromolecules. 2011;9:1387-408

140. Li RK, Jia ZQ, Weisel RD, Mickle DA, Choi A, Yau TM. Survival and function of bioengineered cardiac grafts. Circulation. 1999;100:1163-9.

141. van der Meer P, Voors AA, Lipsic E, van Gilst WH, van Veldhuisen DJ. Erythropoietin in cardiovascular diseases. Eur Heart J. 2004;25:285-91.

142. Kobayashi H, Minatoguchi S, Yasuda S, Bao N, Kawamura I, Iwasa M, et al. Post-infarct treatment with an erythropoietin-gelatin hydrogel drug delivery system for cardiac repair. Cardiovasc Res. 2008;79:611-20.

143. Shao ZQ, Takaji K, Katayama Y, Kunitomo R, Sakaguchi H, Lai ZF, et al. Effects of intramyocardial administration of slow-release basic fibroblast growth factor on angiogenesis and ventricular remodeling in a rat infarct model. Circ J. 2006;70:471-7

144. Takehara N, Tsutsumi Y, Tateishi K, Ogata T, Tanaka H, Ueyama T, et al. Controlled delivery of basic fibroblast growth factor promotes human cardiosphere-derived cell engraftment to enhance cardiac repair for chronic myocardial infarction. J Am Coll Cardiol. 2008;52:1858-65.

145. Yacoub MH, Terrovitis J. CADUCEUS, SCIPIO, ALCADIA: Cell therapy trials using cardiac-derived cells for patients with post myocardial infarction LV dysfunction, still evolving. Glob Cardiol Sci Pract. 2013;2013:5-8.

146. Li Z, Guan J. Hydrogels for cardiac tissue engineering. Polymers. 2011;3:740-61.

147. Huang NF, Yu J, Sievers R, Li S, Lee RJ. Injectable biopolymers enhance angiogenesis after myocardial infarction. Tissue Eng. 2005;11:1860-6.

148. Ou L, Li W, Zhang Y, Wang W, Liu J, Sorg H, et al. Intracardiac injection of matrigel induces stem cell recruitment and improves cardiac functions in a rat myocardial infarction model. J Cell Mol Med. 2011;15:1310-8.

149. Bagno LL, Werneck-de-Castro JP, Oliveira PF, Cunha-Abreu MS, Rocha NN, Kasai-Brunswick TH, et al. Adipose-derived stromal cell therapy improves cardiac function after coronary occlusion in rats. Cell Transplant. 2012;21:1985-96.

150. Kofidis T, Lebl DR, Martinez EC, Hoyt G, Tanaka M, Robbins RC. Novel injectable bioartificial tissue facilitates targeted, less invasive, large-scale tissue restoration on the beating heart after myocardial injury. Circulation. 2005;112:1173-7

151. Kofidis T, de Bruin JL, Hoyt G, Lebl DR, Tanaka M, Yamane T, et al. Injectable bioartificial myocardial tissue for large-scale intramural cell transfer and functional recovery of injured heart muscle. J Thorac Cardiovasc Surg. 2004;128:571-8

152. Laflamme MA, Chen KY, Naumova AV, Muskheli V, Fugate JA, Dupras SK, et al. Cardiomyocytes derived from human embryonic stem cells in prosurvival factors enhance function of infarcted rat hearts. Nat Biotechnol. 2007:25:1015-24.

153. Wall ST, Yeh CC, Tu RY, Mann MJ, Healy KE. Biomimetic matrices for myocardial stabilization and stem cell transplantation. J Biomed Mater Res A. 2010;95:1055-66.

154. Kutschka I, Chen IY, Kofidis T, Arai T, von Degenfeld G, Sheikh AY, et al. Collagen matrices enhance survival of transplanted cardiomyoblasts and contribute to functional improvement of ischemic rat hearts. Circulation. 2006;114:1167-73.

155. Giraud MN, Ayuni E, Cook S, Siepe M, Carrel TP, Tevaearai HT. Hydrogelbased engineered skeletal muscle grafts normalize heart function early after myocardial infarction. Artif Organs. 2008;32:692-700.

156. Zimmermann WH, Didié M, Wasmeier GH, Nixdorff U, Hess A, Melnychenko I, et al. Cardiac grafting of engineered heart tissue in syngenic rats. Circulation. 2002;106:1151-7.

157. Zhang P, Zhang H, Wang H, Wei Y, Hu S. Artificial matrix helps neonatal cardiomyocytes restore injured myocardium in rats. Artif Organs. 2006:30:86-93.

158. Zimmermann WH, Melnychenko I, Wasmeier G, Didié M, Naito H, Nixdorff U, et al. Engineered heart tissue grafts improve systolic and diastolic function in infarcted rat hearts. Nat Med. 2006;12:452-8.

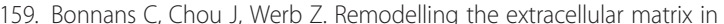
development and disease. Nat Rev Mol Cell Biol. 2014;15:786-801.

160. Badylak SF, Taylor D, Uygun K. Whole-organ tissue engineering: decellularization and recellularization of three-dimensional matrix scaffolds. Annu Rev Biomed Eng. 2011;13:27-53.

161. Midwood KS, Williams LV, Schwarzbauer TE. Tissue repair and the dynamics of the extracellular matrix. Int J Biochem Cell Biol. 2004;36:1031-7.

162. Robinson KA, Li J, Mathison M, Redkar A, Cui J, Chronos NA, et al. Extracellular matrix scaffold for cardiac repair. Circulation. 2005;112:135-43.

163. Song JJ, Ott HC. Organ engineering based on decellularized matrix scaffolds. Trends Mol Med. 2011;17:424-32

164. Crapo PM, Gilbert TW, Badylak SF. An overview of tissues and whole organ decellularization processes. Biomaterials. 2011;32:3233-43.

165. Ott HC, Matthiesen TS, Goh SK, Black LD, Kren SM, Netoff TI, et al. Perfusiondecellularized matrix: using nature's platform to engineer a bioartificial heart. Nat Med. 2008;14:213-21.

166. Dai W, Gerczuk P, Zhang Y, Smith L, Kopyov O, Kay GL, et al. Intramyocardial injection of heart tissue-derived extracellular matrix improves postinfarction cardiac function in rats. J Cardiovasc Pharmacol Ther. 2013;18:270-9

167. Singelyn JM, Sundaramurthy P, Johnson TD, Schup-Magoffin PJ, Hu DP, Faulk DM, et al. Catheter-deliverable hydrogel derived from decellularized ventricular extracellular matrix increases endogenous cardiomyocytes and preserves cardiac function post-myocardial infarction. J Am Coll Cardiol. 2012;59:751-63.

168. Seif-Naraghi SB, Singelyn JM, Salvatore MA, Osborn KG, Wang JJ, Sampat U, et al. Safety and efficacy of an injectable extracellular matrix hydrogel for treating myocardial infarction. Sci Transl Med. 2013;5:173ra25.

169. Perea-Gil I, Uriarte JJ, Prat-Vidal C, Gálvez-Montón C, Roura S, Llucià-Valldeperas A, et al. In vitro comparative study of two decellularization protocols in search of an optimal myocardial scaffold for recellularization. Am J Transl Res. 2015;7:558-73.

170. Seif-Naraghi SB, Salvatore MA, Schup-Magoffin PJ, Hu DP, Christman KL. Design and characterization of an injectable pericardial matrix gel: a potentially autologous scaffold for cardiac tissue engineering. Tissue Eng Part A. 2010;16:2017-27.

171. Fuster V. Hurst's the heart. 13th ed. New York: McGraw-Hill Medical Publishing Division; 2011.

172. Seif-Naraghi SB, Horn D, Schup-Magoffin PA, Madani MM, Christman KL. Patient-to-patient variability in autologous pericardial matrix scaffolds for cardiac repair. J Cardiovasc Transl Res. 2011;4:545-56.

173. Oberwallner B, Brodarac A, Choi YH, Saric T, Anić P, Morawietz L, et al. Preparation of cardiac extracellular matrix scaffolds by decellularization of human myocardium. J Biomed Mater Res A. 2014;102:3263-72.

174. Prat-Vidal C, Gálvez-Montón C, Puig-Sanvicens V, Sanchez B, Díaz-Güemes I, Bogónez-Franco P, et al. Online monitoring of myocardial bioprosthesis for cardiac repair. Int J cardiol. 2014;174:654-61. 
175. Rajabi-Zeleti S, Jalili-Firoozinezhad S, Azarnia M, Khayyatan F, Vahdat S, Nikeghbalian S, et al. The behavior of cardiac progenitor cells on macroporous pericardium-derived scaffolds. Biomaterials. 2014;35:970-82.

176. Wei HJ, Chen CH, Lee WY, Chiu I, Hwang SM, Lin WW, et al. Bioengineered cardiac patch constructed from multilayered mesenchymal stem cells for myocardial repair. Biomaterials. 2008;29:3547-56.

177. Chen CH, Wei HJ, Lin WW, Chiu I, Hwang SM, Wang CC, et al. Porous tissue grafts sandwiched with multilayered mesenchymal stromal cell sheets induce tissue regeneration for cardiac repair. Cardiovasc Res. 2008;80:88-95.

178. Seif-Naraghi SB, Horn D, Schup-Magoffin PJ, Christman KL. Injectable extracellular matrix derived hydrogel provides a platform for enhanced retention and delivery of a heparin-binding growth factor. Acta Biomater. 2012;8:3695-703.

179. Sonnenberg SB, Rane AA, Liu CJ, Rao N, Agmon G, Suarez S, et al. Delivery of an engineered HGF fragment in an extracellular matrix-derived hydroge prevents negative LV remodeling post-myocardial infarction. Biomaterials. 2015:45:56-63.

180. Okada M, Payne TR, Oshima H, Momoi N, Tobita K, Huard J. Differential efficacy of gels derived from small intestinal submucosa as an injectable biomaterial for myocardial infarct repair. Biomaterials. 2010;31:7678-83.

181. Tan MY, Zhi W, Wei RQ, Huang YC, Zhou KP, Tan B, et al. Repair of infarcted myocardium using mesenchymal stem cell seeded small intestinal submucosa in rabbits. Biomaterials. 2009;30:3234-40.

182. Mewhort HE, Turnbull JD, Meijndert HC, Ngu JM, Fedak PW. Epicardial infarct repair with basic fibroblast growth factor-enhanced CorMatrix-ECM biomaterial attenuates postischemic cardiac remodeling. J Thorac Cardiovasc Surg. 2014; 147:1650-9.

183. Badylak SF. The extracellular matrix as a scaffold for tissue reconstruction. Semin Cell Dev Biol. 2002;13:377-83.

184. Kochupura PV, Azeloglu EU, Kelly DJ, Doronin SV, Badylak SF, Krukenkamp IB, et al. Tissue-engineered myocardial patch derived from extracellular matrix provides regional mechanical function. Circulation. 2005;112:1144-9.

185. Kelly DJ, Rosen AB, Schuldt AJ, Kochupura PV, Doronin SV, Potapova IA, et al. Increased myocyte content and mechanical function within a tissueengineered myocardial patch following implantation. Tissue Eng Part A. 2009;15:2189-201.

186. Potapova IA, Doronin SV, Kelly DJ, Rosen AB, Schuldt AJ, Lu Z, et al. Enhanced recovery of mechanical function in the canine heart by seeding an extracellular matrix patch with mesenchymal stem cells committed to a cardiac lineage. Am J Physiol Heart Circ Physiol. 2008;295:H2257-63.

187. Gálvez-Montón C, Fernandez-Figueras MT, Martí M, Soler-Botija C, Roura S, Perea-Gil l, et al. Neoinnervation and neovascularization of acellular pericardial-derived scaffolds in myocardial infarcts. Stem Cell Res Ther. 2015;6:108.

188. Muylaert DE, Fledderus JO, Bouten CV, Dankers PY, Verhaar MC. Combining tissue repair and tissue engineering; bioactivating implantable cell-free vascular scaffolds. Heart. 2014;100:1825-30.

189. Puri MC, Nagy A. Concise review: Embryonic stem cells versus induced pluripotent stem cells: the game is on. Stem Cells. 2012;30:10-4.

190. Giraud MN, Flueckiger R, Cook S, Ayuni E, Siepe M, Carrel T, et al. Long-term evaluation of myoblast seeded patches implanted on infarcted rat hearts. Artif Organs. 2010;43:E184-92.

191. Barallobre-Barreiro J, Didangelos A, Schoendube FA, Drozdov I, Yin X, Fernández-Caggiano M, et al. Proteomics analysis of cardiac extracellular matrix remodeling in a porcine model of ischemia/reperfusion injury. Circulation. 2012;125:789-802.

192. Rienks M, Papageorgiou AP, Frangogiannis NG, Heymans S. Myocardial extracellular matrix. An ever-changing and diverse entity. Circ Res. 2014; 114:872-88.

193. Gaetani R, Doevendans PA, Metz CH, Alblas J, Messina E, Giacomello A, et al. Cardiac tissue engineering using tissue printing technology and human cardiac progenitor cells. Biomaterials. 2012;33:1782-90.

194. Jakab J, Marga F, Norotte C, Murphy K, Vunjak-Novakovic G, Forgacs G. Tissue engineering by self-assembly and bio-printing of living cells. Biofabrication. 2010;2:022001

195. Khatiwala C, Law R, Shepherd B, Dorfman S, Csete M. 3D cell bioprinting for regenerative medicine research and therapies. Gene Ther Reg. 2012;7:1-19.
196. Bader D, Oberpriller JO. Repair and reorganization of minced cardiac muscle in the adult newt (Notophthalmus viridescens). J Morphol. 1977;155:349-57.

197. Vandenburgh HH, Karlisch P, Farr L. Maintenance of highly contractile tissue-cultured avian skeletal myotubes in collagen gel. In Vitro Cell Dev Biol. 1988;24:166-74.

198. Souren JE, Schneijdenberg C, Verkleij AJ, Van Wijk R. Factors controlling the rhythmic contraction of collagen gels by neonatal heart cells. In Vitro Cell Dev Biol. 1992;28:199-204.

199. Eschenhagen T, Fink C, Remmers U, Scholz H, Wattchow J, Weil J, et al. Three-dimensional reconstitution of embryonic cardiomyocytes in a collagen matrix: a new heart muscle model system. Faseb J. 1997;11:683-94.

200. Fink C, Ergün S, Kralisch D, Remmers U, Weil J, Eschenhagen T. Chronic stretch of engineered heart tissue induces hypertrophy and functional improvement. Faseb J. 2000;14:669-79.

201. Zimmermann WH, Schneiderbanger $K$, Schubert $P$, Didié M, Münzel F, Heubach JF, et al. Tissue engineering of a differentiated cardiac muscle construct. Circ Res. 2002;90:223-30.

202. Krupnick AS, Kreisel D, Engels FH, Szeto WY, Plappert T, Popma SH. A novel small animal model of left ventricular tissue engineering. J Heart Lung Transplant. 2002;21:233-43.

203. Radisic M, Park H, Shing H, Consi T, Schoen FJ, Langer R, et al. Functional assembly of engineered myocardium by electrical stimulation of cardiac myocytes cultured on scaffolds. Proc Natl Acad Sci U S A. 2004;101:18129-34.

204. Remppis A, Pleger ST, Most P, Lindenkamp J, Ehlermann P, Schweda C, et al. S100A1 gene transfer: a strategy to strengthen engineered cardiac grafts. J Gene Med. 2004;6:387-94.

205. Khademhosseini A, Eng G, Yeh J, Kucharczyk PA, Langer R, Vunjak-Novakovic G, et al. Microfluidic patterning for fabrication of contractile cardiac organoids. Biomed Microdevices. 2007:9:149-57.

206. Blan NR, Birla RK. Design and fabrication of heart muscle using scaffoldbased tissue engineering. J Biomed Mater Res A. 2008;86:195-208.

207. Lu TY, Lin B, Kim J, Sullivan M, Tobita K, Salama G, et al. Repopulation of decellularized mouse heart with human induced pluripotent stem cell-derived cardiovascular progenitor cells. Nat Commun. 2013;4:2307. 